\title{
C) CREDO
}
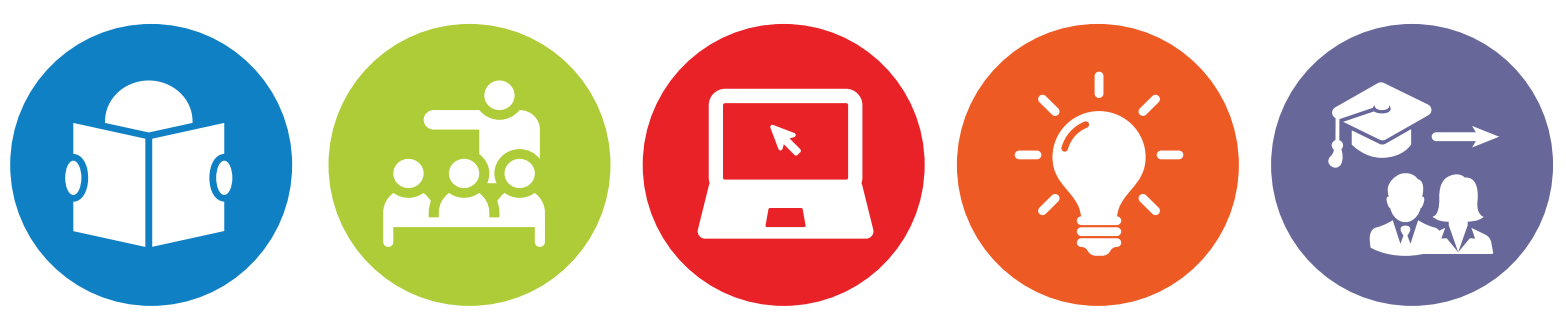

Credo's Interactive FYE Guide:

Practices for Enhancing Instruction 


\section{Table of Contents}

\section{Game of FYE}

FYE Travel through the different sections of our FYE Guide

in this interactive infographic

\section{Chapter 1 - Orientation}

Library Orientation: Maximizing Impact for New Students

\section{Chapter 2 - Collaboration}

Collaborating for Student Success Across Campus

\section{Chapter 3 - Information Literacy}

Building a First Year Information Literacy Program:

Best Practices and Sample Lesson Plans

Chapter 4 - Assessment

Using Assessment to Enhance Teaching and Learning in the FYE

\section{S- Chapter 5 - Student Engagement}

Fun Times in the Library: Fresh Ideas for Engaging Your Students

\section{Case studies}

Overviews of different FYE programs and how they've impacted student success

\section{Infographics}

Creative infographics showcasing activities or sections

within the guide

\section{Additional Resources}

Explore articles, webinars, cases studies, blog posts, and more! 
The Game of

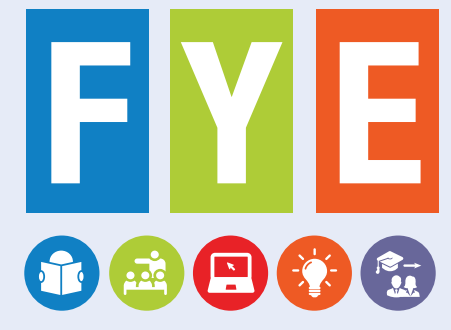

To read about activities in each section, click on an icon!

\section{Orientation}

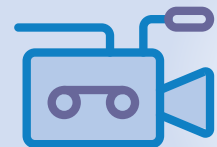

Lights,

Camera...

Library!

Specialized Student Tours

ACTION CARD

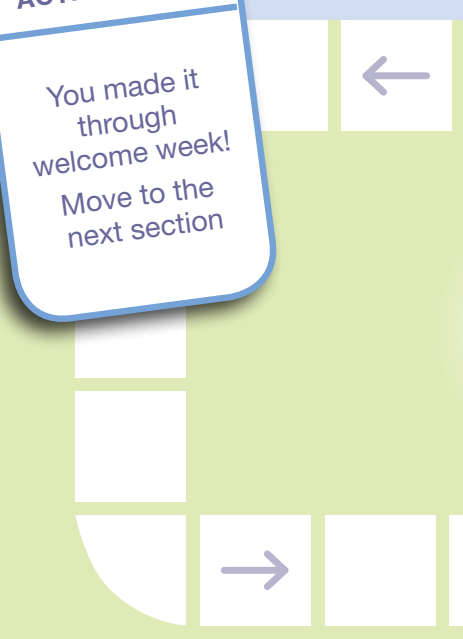

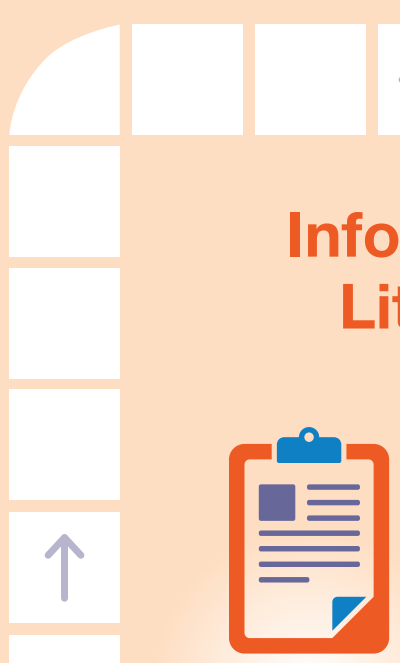

Refresh Your Lesson Plan $\longrightarrow$

nformation Literacy

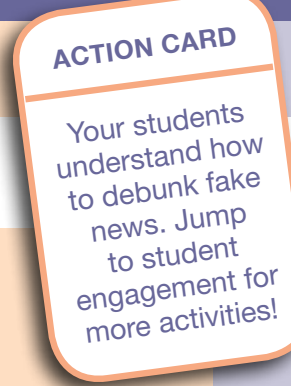

\section{how} p for

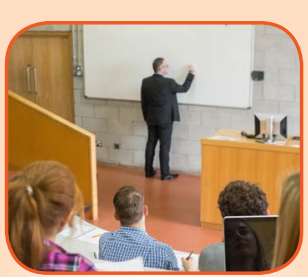

Multidisciplinary Studies Intruction

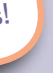

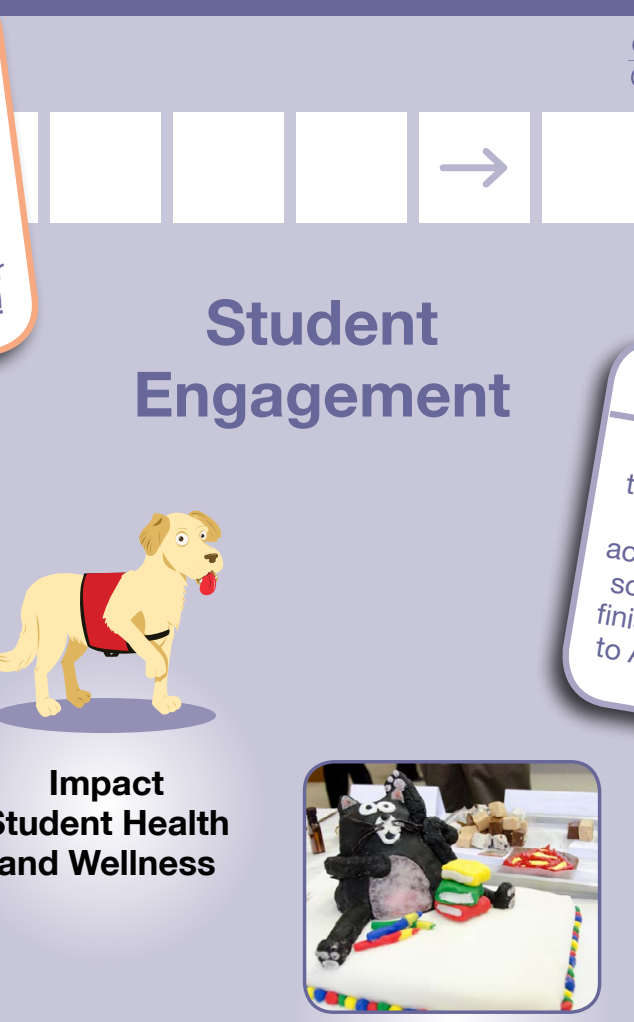

Edible Book Fair
CQ CREDO
ACTION CARD

The English 101

professor uses

library libguides

with students.

You're ready for IL!

\section{Collaboration}

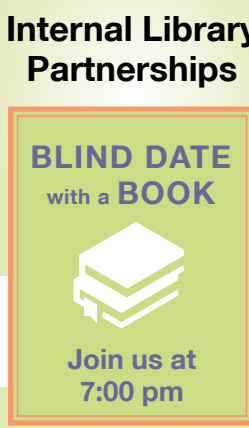

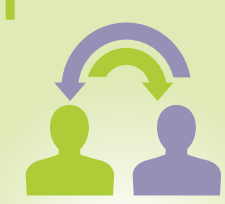

Sync up with Student Affairs

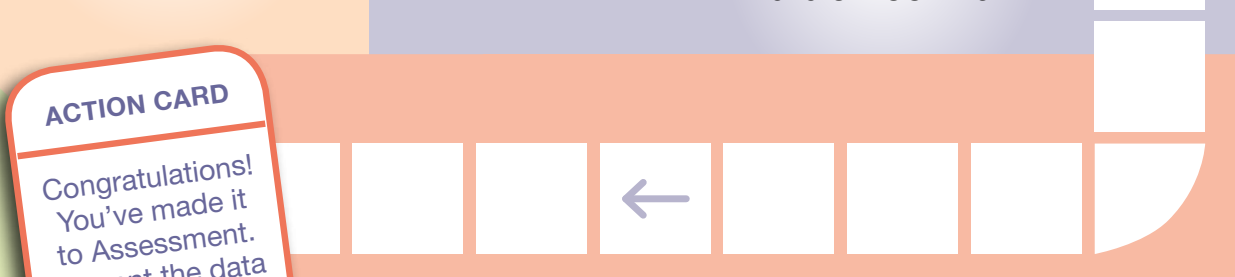

to Assessme data

Present captured

from student

from students.

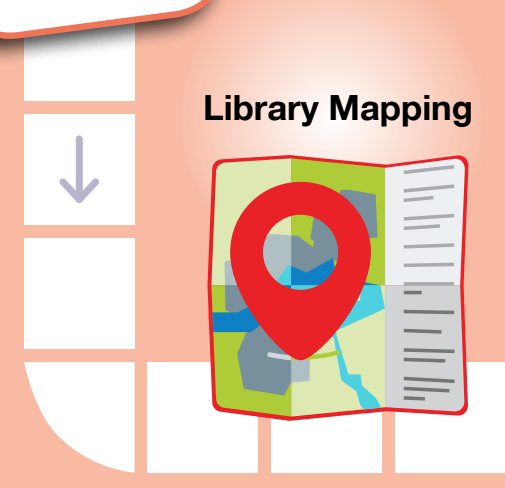

\section{Assessment}

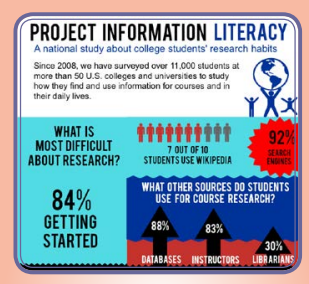

Market Your Value 


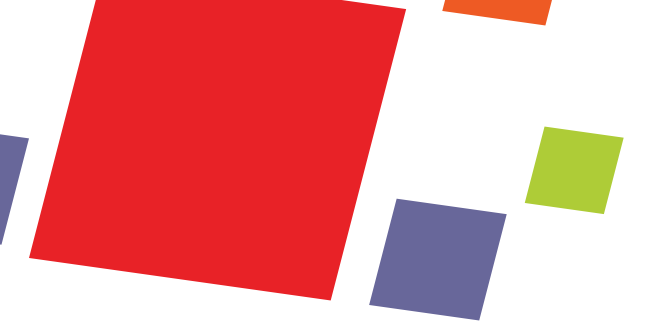

\section{C) CREDO}

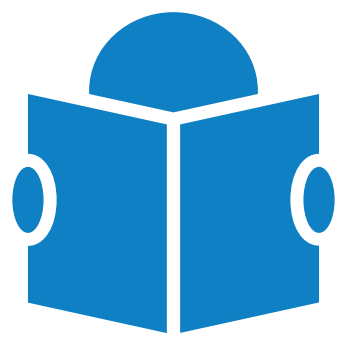

\section{Chapter 1: Orientation}

Orientation can be considered the launching pad for a successful First Year Experience program. Generating student excitement at the beginning of the school year can yield positive outcomes related to everything from student retention, to GPAs, to classroom engagement and eventually even into success in the workplace. Use the tools in this chapter to make a lasting first impression with students and set them on the right path for a great first year experience! 
By Ray Pun, First Year Student Success Librarian, California State University, Fresno

\section{Do you recall your library orientation experience when you were a first year student?}

For most of us, probably not. As for me, the only memory I have is a librarian saying the library does not own textbooks for us to borrow. This gave me the impression I didn't need to visit or use the library until much later. Over the last decade however, libraries have changed quite a bit, providing much needed services, resources, and

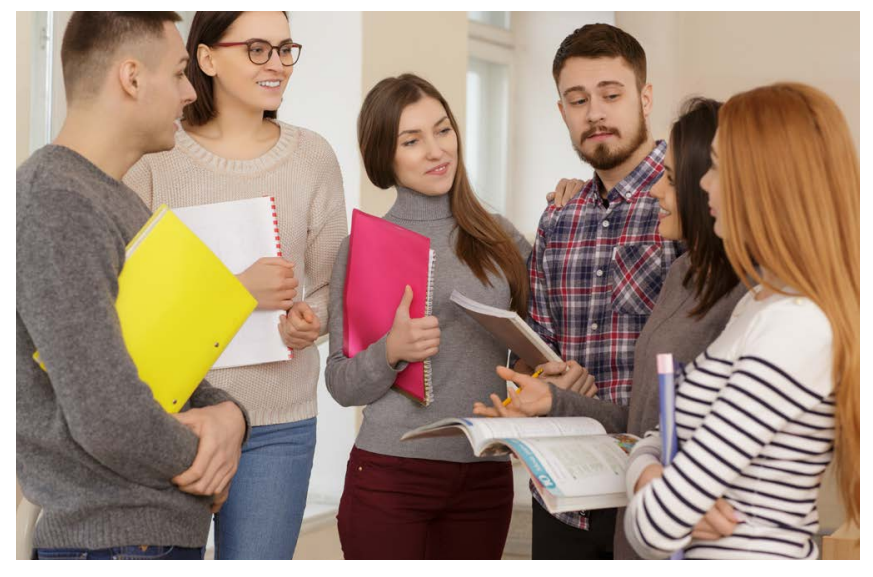
support to students at all levels.

At the beginning of each academic school year, waves of new students arrive on campus and struggle to make sense of their surroundings and classes. For librarians, this presents an opportunity to introduce incoming students to various services to support their needs during the academic year. Many research studies suggest students, particularly incoming first year students, may have "library anxiety" and/or may feel unsure of how to use the library or ask a librarian for help. Engaging with students in library orientations can help reduce the feeling of library anxiety and foster new relationships between students and librarians.

In this section, we will explore different types of orientations, with suggestions and examples of activities and best practices geared towards first year students, international students, transfer students, and distance learning students.

\section{First Year Student Orientations}

As the saying goes, "first impressions are the lasting ones." The same applies to first year students!

\section{EGTS about the Henry Madden Library that you should know!}

What are some ways to engage with first year students? Some librarians will give in-person overviews of library services during summer sessions, such as summer bridge programs. Others may show videos (see Fresno State's library orientation video) that briefly introduce important services and resources for first year students. Although preparing a video may take time to create initially, it's a great resource to be able to reuse with different incoming classes. 
Library Orientation: Maximizing Impact for New Students

\section{fin In-Person Orientations}

If your institution requires in-person orientations for incoming students, check out the the ACRL Framework for Information Literacy Sandbox to find a wide range of activities, from making zines to teaching basic research skills. These lessons come from The First Year Experience Cookbook and can provide a creative ways to introduce library resources to your new first year students.

\section{Interactive Games}

In lieu of library tours, some academic libraries have used scavenger hunt games to engage students. Long Island University Libraries created The Amazing Library Race based on the popular reality TV show. In this type of activity, students work in groups through a series of challenges while exploring various spaces within the library to learn more about the services and resources. At the end, winning teams may receive prizes! To make sure your scavenger hunt is successful, try out the game with your colleagues first.

\section{Welcome Programs}

"Welcome" programs are another way to orient your students for the new academic school year. For example, you can organize a photo booth in front of your library for anyone to participate in. This can be a nice way for students to feel connected to the library and to share their photos and thoughts on social media platforms like Instagram or SnapChat. For this type of activity, schools have either rented a photo booth from an outside vendor, or created their own DIY photo booth using digital cameras, props, and other technologies hosted in the library.

\section{School Swag, Prizes, and Giveaways}

If you have a modest budget, consider investing in "swag" items for prizes or giveaways. Some popular items among students have been: microfiber cloths to clean surfaces of cellphones and eyeglasses, multi-charging cables for USB to Apple Devices, or phone wallets for storing cards. Some schools give out USB flash drives, t-shirts, sunglasses, and academic planners too. Adding your school logo on swag items can be a nice touch as well.

Engaging with first year students can be challenging, but fun. To keep your students engaged and continue to promote library services throughout their academic career, it helps to have some creative and out-of-the-box activities to use! 


\section{International Student Orientations}

Orienting students who come from different parts of the world can be challenging. Have you thought of creative ways to introduce "American-style libraries" to your international students? Some academic libraries have organized a series of workshops on this topic, while others have partnered with their international student office to provide a general orientation and tour. Below are some examples to use with your new international students.

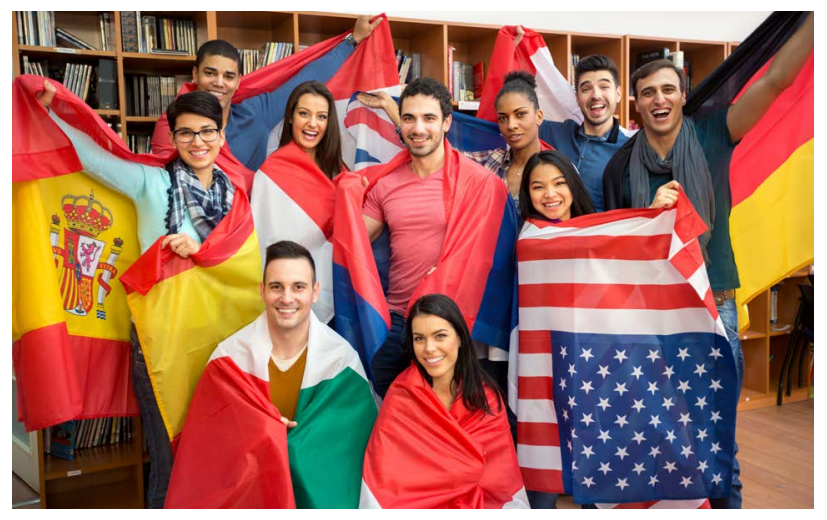

\section{International Student Tours}

Offer tours catered to international students highlighting the services and resources your international students might really need:

》Does your library have a prayer/meditation room for those who might be religious?

》Is there a section for foreign language collections in your library?

》Where are the tutoring or writing centers in the library located?

»Are there quiet study spaces available to use?

These are some questions you may want to go through in your tours with international students.

\section{Alternative Language Orientation}

Some academic libraries may offer library orientation in different languages. The University of Pittsburgh Library System for example, has orientations in Chinese-Mandarin for their new Chinese students. If you have colleagues who can speak other languages, this can help create meaningful conversations and presentations for international students for whom English is a second or third language.

\section{Transfer Student Orientations}

Students transferring from another institution may struggle to figure out their new campus environments at first, and may be reluctant to ask for assistance when looking for necessary resources. Collaborating with your school's office for transfer student services by attending their events, workshops, and fairs is a great way to begin to think about outreach toward transfer students.

Here are some additional ideas from institutions who provide orientation services for this often overlooked population: 


\section{Library Orientation: Maximizing Impact for New Students}

\section{University of North Carolina at Wilmington}

Tammy E. Ivins, Transfer Student Services Librarian has a deep involvement in several programs surrounding transfer students. She hosts office hours in the campus' Military Resource Lounge, provides outreach workshops, and visits some of the feeder community colleges to meet with incoming transfers in order to provide better library sessions for these students.

\section{University of North Carolina at Chapel Hill}

This university created a "personal librarian program" for transfer students to support their academic development. When their case study suggested a more personalized approach could offer an effective way for libraries to better support transfer students, they began connecting subject librarians with transfer students majoring in similar fields.

\section{University of California, Merced}

The University of California, Merced's library created this LibGuide, covering ten important things transfer students need to know. The LibGuide is a quick and easily accessible resource to acclimate transfer students with their new environment.

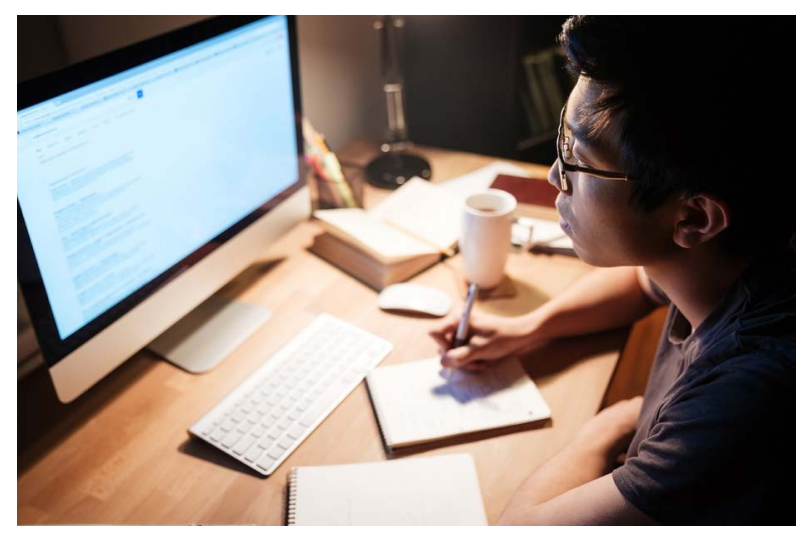

\section{Online Distance Learning Student Orientations}

There are some students you may never see or interact with. How do you orient them with library resources and services when they may not be close to the university at all? Many academic libraries utilize LibGuides to feature library orientations through videos and tutorials. If you don't have access to LibGuides, there are some alternative ways to engage and encourage participation.

Here are some creative examples:

\section{Hillsborough Community College}

Hillsborough Community College Libraries created an online library orientation for their students. The LibGuide allowed librarians to connect with students through a straightforward, simple, and clear introduction to library services and resources.

\section{Penn State University}

Penn State University Libraries created a LibGuide featuring digital badges, a very popular trend in higher 


\section{Library Orientation: Maximizing Impact for New Students}

education today. Students are encouraged to attend the online orientations, and in doing so, earn a badge. If your university has a badging system, this is a creative way to incentivize students to learn more about library services online.

\section{California State University, Fresno}

This library created an online library orientation game. While this type of activity may require some inperson components for those who live nearby, it can help online students develop a sense of belonging with the library. If you are considering this approach, it is helpful to design a game that connects closely to library orientation services. Some mobile apps to consider using for design are Social Scavenger or Eventzee.

\section{Additional Options}

If you don't have access to LibGuides, some alternative options include WordPress, Weebly, or Wix, or using your university's existing learning management systems including Canvas, Blackboard, or Moodle.

You can also browse YouTube for library orientation videos you can adapt to fit your institutions needs or gather inspiration!

\section{Conclusion}

Designing an orientation program to fit your institution's needs can come in all shapes and sizes. From in-person tours and presentations to online activities, there are so many resources available to experiment with as you setup your orientation. Not all orientations are alike; orientation events can be hosted throughout the fall semester and in different settings. When you're planning an orientation event or activity, be sure to alert your campus partners and teaching faculty to get the word out to the new students coming in!

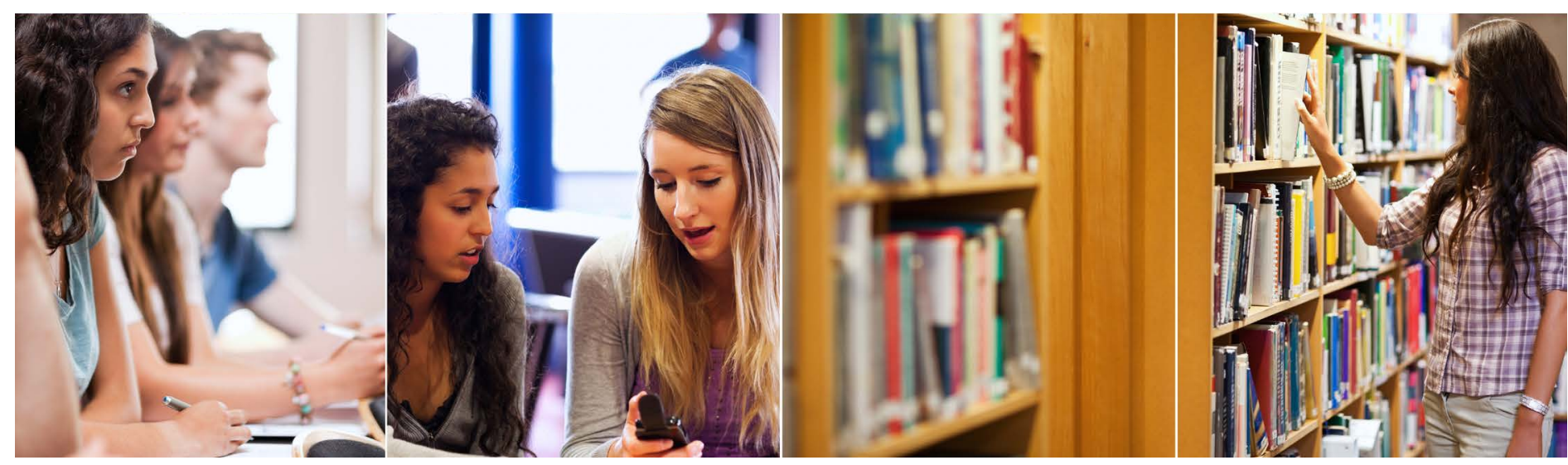

\section{CREDO}




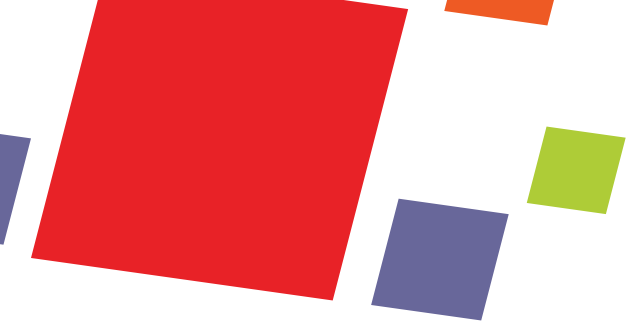

\section{()}

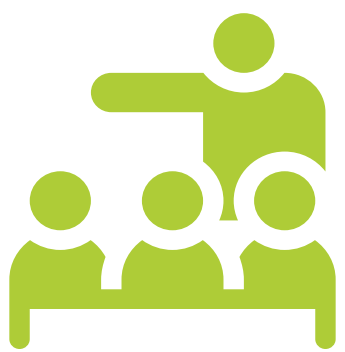

\section{Chapter 2: Collaboration}

It is important to remember your library is not alone when it comes to supporting first year students. Forming partnerships with various groups across campus is instrumental in engaging new and existing library users, promoting services, and raising awareness of the library's many resources.

In this chapter, we'll look at strategies and best practices you can use to showcase the value and strengths of your library! 
By Ray Pun, First Year Student Success Librarian, California State University, Fresno

\section{Internal Collaboration Within the Library}

Look for opportunities to work collaboratively with your colleagues under the same roof.

\section{BLIND DATE WITH A BOOK OR MOVIE!}

February $9-17$

1. Pick a book or DVD at random

2. Check it out at Circulation

3. Unwrap and go on your blind date

We Hope You Make A Love Connection!

\section{Creating engaging displays}

You can host a book display featuring wrapped books, where users select books at random to read for fun. This 'Blind Date with a Book' activity is designed to attract students to the library by promoting leisure reading. A nice touch can be setting this up during a holiday like Valentine's Day, National Single's Day, or National Library Week. Best of all, all library staff will enjoy participating.

To truly make this a team effort, find different roles members within your library can play.

- Technical services colleagues can process selected books and DVDs to be included in the display.

- Public services members can wrap the materials, and promote it as a fun engagement activity.

- Student assistants can brainstorm ways to promote the display to their peers.

Tip: Photocopy each item's barcode and tape it to the outside of the wrapping so that the student won't have to unwrap it until they're ready to meet their new book.

\section{Promoting Diversity Awareness in Library Exhibits}

Work with your fellow library staff to increase students' diversity awareness by creating displays and pop-up exhibits, all while shining a spotlight on the library's collections. Some popular themes include International Education Week, Black History Month, National Women's History Month, Veteran's Day, Asian Pacific American Heritage Month, and Hispanic Heritage Month. Any of these can provide a great opportunity to promote your library content; from maps, to multimedia items, to digital and print books. Your team can also work together on additional resources like bibliographies to showcase your resources.

\section{Creating Engaging Social Media Content}

Social media is a critical tool for exposing library content, sharing resources, and promoting services. Oftentimes, a library's social media manager is expected to come up with all of this content on their own, however, this can lead to some blind spots. Bringing in other library members can offer a more comprehensive look at what the library has to offer beyond updates to hours, event notifications, and finals-related memes.
What are some

activities you've tried

to increase awareness

of your library's diverse

collections or cultural

artifacts?

< Click here to check

out multicultural

calendars online for ideas on upcoming themes

\section{CREDO}




\section{Collaborating for Student Success Across Campus}

- Feature your colleagues in short, behind-the-scenes stories. This can help humanize library staff, while explaining the roles of different staff members.

- Promote services like open educational resources or course reserves so faculty and students can see how easy library services are to use.

- When a colleague creates a display, encourage a conversation with the social media manager to promote it in a way that provides more than the standard title and picture.

- Brainstorm with colleagues at all levels of the library to gather more ideas, information, and sources to promote.

\section{Teaming Up With Student Groups}

One of the primary objectives of any FYE program is to cultivate deeper and more personal ties between students and their institution. It is imperative to tap into student groups on campus to foster those relationships, while introducing many of these students to the library for the first time. Reach out to student groups, clubs, and government, to see if you can find mutually beneficial projects that may serve to broaden the library's role. If given the opportunity, to sit in on students' group meetings, attend their events, or serve as a mentor or advisor.

\section{Co-Curating Book Displays}

Inviting students to help set up a temporary display is an easy, low-pressure activity to engage various groups. Let the students select which resources will be put on display, design signage, and promote through their social media channels. Below are some questions to consider when brainstorming for potential student collaborations:

- Are there student clubs (e.g. film, anime, horticulture, etc.) who would appreciate the opportunity to share their passion with fellow students?

- Would student government members like to curate books about leadership or politics that influenced and inspired them?

- Can you think of organizations who want to provide a voice for overlooked, marginalized, or underrepresented populations?

- Do you have international students who may want to bring attention to their home country's authors, poets, and history?

\section{C) CREDO}


This can be a fun exercise for students to learn about library resources and feel engaged because they contributed to a public display. If they need help selecting a theme, consider events like "Banned Book Week" in September or "Picture Book Month" in November. Students may even have suggestions of books you should add to your collection as well!

\section{Lights... Camera... Library!}

With the recent drop in costs related to video creation and editing, Library Video Contests have emerged as a fun and affordable way to engage students. Academic libraries like UC Irvine Libraries have promoted this type of contest to increase student engagement and participation.

\section{Some popular FYE takes on video contests include:}

- Sharing a library success story

- Solving a research assignment mystery

- Travel guides to your favorite library spots

If your library lends out video equipment, all the better. If nothing else, you can point students toward library materials on topics like film, editing, and cinematography to inspire them. Make sure your contest guidelines focus students on highlighting the library space and resources and set clear limits on run time, file type, and participation.

\section{Partnering With Teaching Faculty}

When Credo conducted an informal booth survey at the 2017 ACRL Conference, librarians spoke to their frustration in attempts to collaborate with faculty. $\mathbf{7 1 \%}$ said the biggest obstacle to engaging with faculty was, "faculty underestimating the value of the library." Below are some programming ideas to go beyond the conventional information literacy one-shots and course reserves. Some of these ideas may help faculty realize the value of the library.

\section{Building Information Literacy Standards for FYE}

Information Literacy is becoming an integral part of instruction in first year student courses. More and more, librarians are being asked to support IL initiatives. The case study in this chapter reviews how the libraries at Bryant University and Dickinson college changed the culture around information literacy at their institutions. In both cases, partnerships with campus departments were essential to their success. Starting communication with your teaching faculty can open the gates to a collaborative teaching environment.

Do your teaching faculty members know about information literacy standards, outcomes, and frameworks?

\section{C) CREDO}


Consider meeting with faculty members who teach FYE (especially in the English or Communication Studies departments) to brainstorm ways to introduce IL resources. This will make their lives easier-nobody wants to grade a pile of bad research papers - while raising awareness of library resources and services. You can provide additional support by working with them to build an information literacy rubric for assessing first year students. This can help build relationships with teaching faculty and enhance the library's role as a credible teaching partner. Start small, using informal lunch meetings to discuss how information literacy can be incorporated in the FYE.

\section{Organizing Research and Writing Awards}

Undergraduate research is listed by the AAC\&U as one of ten "High Impact Educational Practices" known to increase student retention and engagement. They suggest the excitement that comes with "working to answer important questions" is extremely beneficial to students. Recognizing outstanding student research is

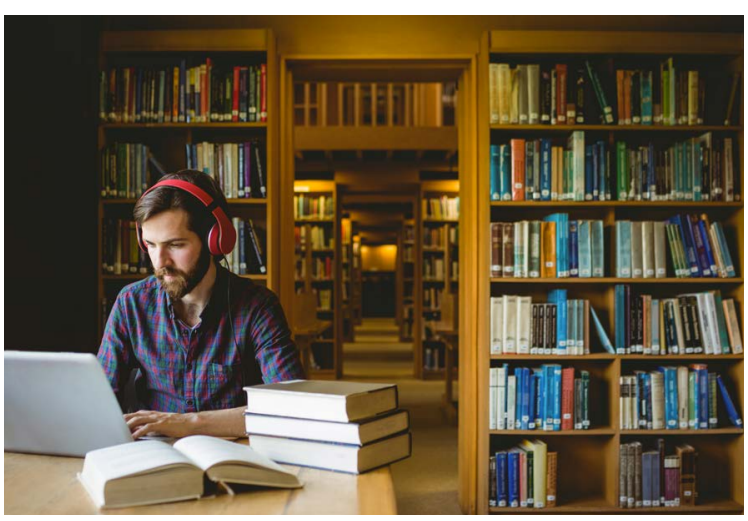
a way to build upon this practice, while simultaneously raising awareness of the role your library plays in the research process.

Many libraries including UC Berkeley Library, University of Maryland Libraries, and UCLA Library have joined with faculty to host annual awards contests to recognize students with the best undergrad research papers. The key is combining research techniques and processes learned in the library with writing instruction in the classroom.

Tip: Have students include a reflection paper on how they defined their topic, conducted their research, and used library resources. This insight can help improve instruction, library services, and resources.

\section{Inviting Poster Presentations and Conferences}

Physical space is one of your library's greatest assets - take advantage of it to entice faculty members to use the library during class time! Whether for student presentations or organizing a mini-conference, this resource can give faculty the opportunity to enhance students' experiences. Hosting events in the library can entice community members or other students to visit the library. While tricky in terms of size and logistics, these activities demonstrate how the library supports faculty efforts.

\section{CREDO}




\section{(8) Joining Forces with Student Affailrs}

Student Affairs or Student Services is a great but often overlooked ally for librarians supporting the FYE.

Coordinating with them can offer several opportunities to increase student engagement.

\section{Partnering with Writing/Tutoring Centers}

Writing and tutoring centers and the library's goals are often similar if not the same. Librarians and tutors working together to co-teach research skills is a great partnership to form! Expanding the library's role as a teaching partner can help introduce yourself and the library's services to a broader group of new students.

To further support these centers, libraries can organize "pop-up events" or "write-ins", where students can gather, write, and discuss what they're working on. If the writing/tutoring centers are not in the library, offering the library as a space to work with students, especially during midterms and finals, can help place students closer to the resources they need to write their best papers.

\section{Serving as Advisors for At-Risk Students}

There are many ways to encourage students and help them manage their academic journey. One approach is through Student Affairs departments like Fresno State's SupportNet, "an early support program where faculty and staff can refer students who need academic and/or personal assistance." Librarians can serve as referrals to help students who are deeply struggling with their research papers and are embarrassed to ask their professors or peers for help. Providing support and counseling to these students supports Student Affairs' efforts, and promotes retention and success.

\section{Helping Meet Students' Most Basic Needs}

Last year The Chronicle of Higher Education published an article about college students who have to choose between buying food or textbooks. In it, they cite several surveys revealing staggering numbers of college students who are experiencing hunger. Many schools have introduced hunger and food security programs where students can receive free food without question.

What role can the

library play with

students who face

socioeconomic

challenges?

\section{Libraries can provide access to food and alleviate textbook costs by:}

- Working with Student Affairs to establish food banks

- Advocating for more OER content with teaching faculty

- Purchasing digital textbooks for multiple usage

Note: If your institution has an upward bound program, you can coordinate with Student Services to ensure those students receive the support they need.

\section{C CREDO}




\section{(10ix Community Partnerships for Success}

\section{Don't be afraid to go off campus to look for partners who can help enrich your FYE initiative.}

\section{Public Library Collaborations}

To foster a partnership with your public library, consider reaching out to offer a visit to your space and sign up eligible students and faculty for library cards. This is a win-win situation; they'll appreciate the opportunity to increase their membership, while students and faculty will benefit from learning about community programs and resources. This kind of introduction can present an opportunity for the public library to enlist students to help with literacy initiatives, technology services, and more.

\section{Engaging with Other Universities, High Schools, or Community Colleges}

Conferences like ALA and ACRL can provide great networking opportunities, but setting aside time to meet with outside institutions in your community is a great way to forge relationships and share ideas. You can organize short trips with your colleagues to visit surrounding institutions and learn about their students, ideas, and programs.

If you work at a large public university, have you spoken to librarians at the feeder schools and community colleges that often send students your way? Learning about students' needs and challenges can help you prepare and plan for the best way to support them at their current levels. Vice Versa, if you work for a community college, learning more about the local university library can help you prepare students who decide to transfer.

Do you know the

history of your

How can you

uncover your

history/stories? community?

\section{Working Together to Build Community Archives}

Many academic libraries, such as the University of North Carolina-Chapel Hill, have organized events on oral histories and community archives to support and preserve local histories. Partnering with teaching faculty and their classes, along with a community group, is a creative way to organize and build an oral history or digital storytelling archive. Students can have roles too, serving as interviewers and transcribers. This activity requires several key partners including colleagues in special collections, community groups, and teaching faculty to ensure the activity is accurate; and stories can be used for future research.

Collaboration can be a fun and exciting way to reshape, reimagine, and reconfigure how we present our libraries. Our support for teaching, learning, and engagement can lead to stronger and more fruitful relationships with teaching faculty, student groups, community members, and other campus partners! 

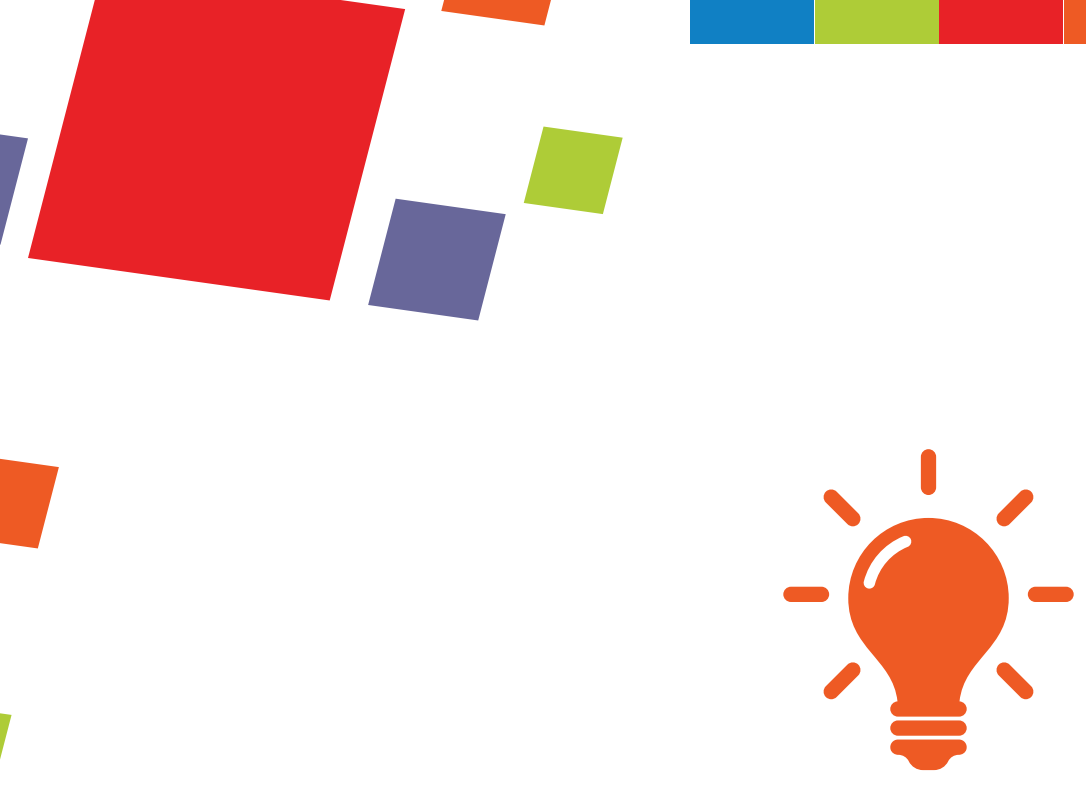

\section{$\frac{C}{\mathrm{C}} \mathrm{C}$ CREDO}

\section{Chapter 3: Information Literacy}

Information literacy is at the heart of a FYE librarian's work; it is the foundation for students to develop strong research skills, write thoughtful papers, and achieve success in the classroom. We know the majority of students do not arrive on campus with strong IL skills, and many have ingrained misconceptions that need to be corrected. Librarians have a number of opportunities they can use to teach students including one-shots, embedded librarianship, FYE seminars, and more-all with varying levels of buy-in and understanding from faculty. In this chapter we will explore new research and innovative case studies, lesson plans, active teaching techniques to strengthen your library's instruction strategy, and more. 


\section{Building a First Year Information Literacy Program: Best Practices and Sample Lesson Plans \\ By Ray Pun, First Year Student Success Librarian, California State University, Fresno}

\section{First Year Information Literacy in One-Shot}

Many of us have taught one-shot workshops for first-year writing classes, communications classes, or freshmen seminars. To make the most of these workshops, integrate creative activities to help engage with students and their learning processes. Some librarians have deconstructed the "one-shot" model, embedding themselves in a given class multiple times during the semester (we will get to embedded librarianship sessions later in the section). For those who are committed to teaching one-shot workshops, the sample lesson plans* below can help you integrate the ACRL Frames.

Lesson Plan \#1

\section{DELIVER RESEARCH BASICS 101 IN A ONE-SHOT}

Prior to

Class

In-class

Activities
Speak with the instructor to gather information about the class. Ask for a copy of the syllabus or specific assignment you're supporting.

$\checkmark$ Design a general or specialized workshop to support the research assignment.

$\checkmark$ Plan to hold the class in a computer lab.

Note: If labs aren't available, instruct students to bring their laptops or, if possible, allow them to borrow one from the library.

\section{Introduce library resources, research guides, offerings and/or services}

Consider using the Cephalonian Method when going through library resources. The images can be related to parts of the library or school. You can spend time during the activity explaining what the images represent.

$\checkmark$ Introduce non-library services such as the writing center or tutoring center and explain how these services can help with writing papers.

\section{Test Students' Memory}

Help students remember resources found on the library's website by having them draw the website from memory and discuss the drawings with a partner.

$\checkmark$ After the discussion, you can show students the website again and explain what is available in different sections.

\section{Engage Students in Early Morning Workshops}

Consider an activity in which students move around and feel engaged.

To start the workshop, have students answer a question on a piece of paper: 'what does research mean to me?' 


\section{Building a First Year Information Literacy Program: Best Practices and Sample Lesson Plans}

\section{DELIVER RESEARCH BASICS 101 IN A ONE-SHOT (cont'd)}

"Divide the class into two groups, one on each side of the room.

" Have them fold their paper into paper airplanes and throw them across the classroom.

" Each group member will pick up an airplane from the other side and read it aloud to stimulate discussion.

\section{Explore Topics and Keywords}

In many classes, students are asked to develop topics or identify suitable keywords to use when searching for resources.

$\checkmark$ A great visual tool to stimulate keyword searching is Credo's Mind Map.

$\checkmark$ You can also use a whiteboard to create a 'mind map' with the students and have them generate keywords around a topic.

\section{Keep Large Classes Engaged}

With larger classes (more than 50 students), it may be hard to keep all students engaged and on the same page.

Peer-to-peer activity is great to keep all of your students engaged - after explaining what a scholarly article is and where to find one online, you can have students team up to look for scholarly articles.

In-class

Activities

$\checkmark$ Consider using open collaborative tools in this activity such as Google Sheets or Padlet. Using these tools, students can input citations or list databases, keywords, or responses to the questions that you have created.

"This activity can help students engage with the class by adding their information to the spreadsheet so that others can see it.

Helpful Tip: Make sure Google Sheets is editable for all and assign individual cells for the class to fill.

\section{Integrate and Map Frames into Workshops}

There are numerous ways to introduce the ACRL Frames in your workshops. (Check out the Additional Resources section at the end of the chapter for more ideas!)

One way to use the ACRL Framework is to map out core concepts of a given assignment or the learning outcome(s) of the class/syllabus. This can help you design activities or facilitate discussions under these synthesized guidelines.

" Example 1: Scholarship as Conversation frame - If you are having students learn about the anatomy of a scholarly article, put them into pairs to discuss what a scholarly article is and see who is or isn't having a scholarly conversation.

" Example 2: Information as Value frame - Use a "think + pair + share" activity to teach academic integrity and plagiarism. Present a series of examples of plagiarized, semi-plagiarized, and paraphrased statements, and have students work through them as a group. 


\section{Building a First Year Information Literacy Program: Best Practices and Sample Lesson Plans}

\section{DELIVER RESEARCH BASICS 101 IN A ONE-SHOT (cont'd)}

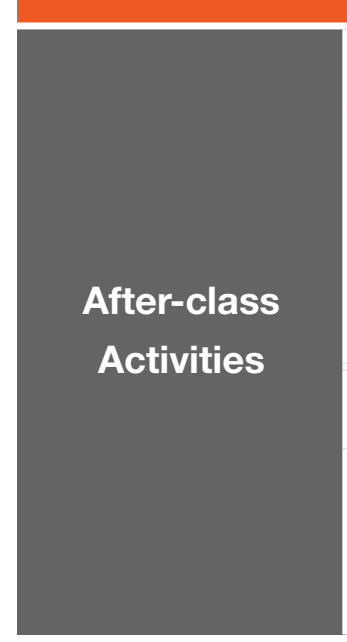

\section{Get feedback}

Save the last 5-10 minutes of class time for students to fill out a survey about your class and what they've learned so you can make workshop improvements.

Ask students to complete a one-minute reflection on an index card indicating what they understood or still don't understand.

\section{Debrief}

Have students share and discuss their experiences and findings after the research/ searching activity. The instructor may also want to share follow-up assignments in the class.

\section{FAKE NEWS DETECTION}

Speak with the instructor to gather information about the class. Ask for a copy of the syllabus or specific assignment you're supporting.

Prior to Class

$\checkmark$ Design a general or specialized workshop to support the research assignment.

Plan to hold the class in a computer lab.

Note: If labs aren't available, instruct students to bring their laptops or, if possible, allow them to borrow one from the library.

\section{"Gamify" Library Instruction}

Digital tools - From Kahoot! to Padlet, there are many digital tools that include information literacy tutorials with interactive features for gamifying library instruction.

In-person games - If you have limited technology, create a scavenger hunt. Have students follow a series of clues around the classroom about the different types of resources available in the library.

In-class

Activities

\section{Teach Fake News Detection}

Provide news items for students to explore on their own. Use sources such as clickbait sites, satire, The Onion, etc.

Exercise Idea 1 - Professor Melissa Zimdars from Merrimack College created this open source list showing sites that present fake news. Have students examine sites on the list and compare the information found on them to information in library databases. This can teach the class to analyze sources critically. 


\section{Building a First Year Information Literacy Program: Best Practices and Sample Lesson Plans}

\section{FAKE NEWS DETECTION (cont'd)}

Exercise Idea 2 - For this assignment, students create fake Twitter accounts and disseminate information from fake-news websites in the social media world, watching to see the traction fake information gets. This can teach them about the repercussions and confusion spreading "fake news" can cause and how social media is changing information and news today.

Activity support: Consider using the RADAR Framework Loyola Marymount University Library created to evaluate fake news.

\section{Teach Primary and Secondary Literatures in the Sciences}

In-class

Activities
Consider an interactive activity to teach students how a scholarly article is constructed, based on explaining different parts of its anatomy: abstract, introduction, thesis/research questions, conclusion, and references.

Activity Example (works well in small and large classrooms) - Print out a series of scientific articles relevant to the course, cut each article into different pieces, and put into envelopes. Students will work in groups to put the article in their envelope back together with scotch tape. Once all groups have completed the activity, have them find the article's abstract and paraphrase it. Afterwards, explain what a primary or secondary article in the sciences is. Finally, students should explain the article they have and identify which type of article it is.

From this exercise, students should gain a better understanding of how a scholarly articles are constructed and know how to find them in library databases.

\section{Embedded Librarian and First Year Information Literacy in Multidisciplinary Studies}

Teaching information literacy to FYE students should not be limited to teaching databases. There are a number of creative ways to engage with students' learning and critical thinking skills that richly connect to other fields and studies. Below is a lesson plan with themes and activities to consider when broadening your teaching program. Regardless of the subject, these activities can be scaffolded and built into multiple sessions if needed. 


\section{Building a First Year Information Literacy Program: Best Practices and Sample Lesson Plans}

Lesson Plan \#3

PROVIDE IL IN MULTIDISCIPLINARY FRAMES

Incorporate Critical Pedagogy and Social Justice in Instruction

The Critical Library Pedagogy Handbook is a great place to uncover teaching strategies focused on social justice topics.

$\checkmark$ One assignment can focus on students' understanding of different perspectives on specific groups or issues, such as LGBTQ groups or undocumented and other immigrants. Have students conduct research, finding a primary and a secondary source on the group's experiences.

You can also direct students to think more broadly about the legal, economic, political, and cultural assumptions regarding marginalized communities. Some discussion starters include:

- Why is it important to have multiple perspectives?

- If we had a single perspective, what would be missing?

- What else do we know or want to know related to this perspective?

The goal of this assignment is to encourage students to think, reflect, and research these issues and perspectives, understanding the gaps in resources and their misinterpretations, and identifying how to reconcile opposing views or claims.

$\checkmark$ If an assignment like this is out of scope for your work, you can use social justice topics when demonstrating how to use a search engine in a library database-it's a good first step to start students thinking about societal issues and finding related available resources.

\section{Social justice is an important consideration for library instruction - students learn how to use information to dismantle inequity, systematic racism, and biases.}

\section{Address Multiple Literacies, Such as Visual and Data Literacy}

You can address many underlying issues that connect directly to the ACRL Frames using visual literacy exercises and a series of questions.

$\checkmark$ Exercise 1 - Have students search for images in a library database such as Credo and explain the meaning behind the images using the questions below:

"What do they mean?

"What do they tell us?

"When was the image created?

"For whom was it made?

"What are the cultural, political, or economic assumptions of the visual? 


\section{Building a First Year Information Literacy Program: Best Practices and Sample Lesson Plans}

\section{PROVIDE IL IN MULTIDISCIPLINARY FRAMES (cont'd)}

Have each student find an image and discuss its relevance with a partner. During this exercise, show students where to find free images, how to cite images, and address the issues of copyright, fair use, and licensing.

Exercise 2 - In a related exercise on data literacy, similar questions can be asked regarding charts and graphs students are tasked with finding.

»Once students find a data set in a database, they can talk about it with their class partner and answer the questions listed in Exercise 1.

》Explain that while the data they find may not always give a complete picture or story, it is always necessary to ask further questions.

»Be sure to show students how to cite graphs/charts in their papers too.

\section{These two sample exercises can support interdisciplinary studies, addressing important research sources: images and numbers.}

\section{Integrate Special Collections and Wikipedia Into Your IL Work}

Collaborate with colleagues in other departments to expose unique resources from your library's archives or special collections. Bring special objects or documents for students to look at, think about, and ask questions about, such as:

》What is the time period of the object?

"What is the context of the object's authorship?

"What is its purpose?

$\checkmark$ Have students conduct Wikipedia research on these items and locate notable gaps in the information on the site. This activity will demonstrate that not every object or document is well-represented digitally.

$\checkmark$ Many instructors tend to shun Wikipedia, but it is a rich tool for teaching research skills.

» Activity Idea: Students can participate in a Wikipedia "editing session" using special collections or print/digital reference sources, including Credo, to improve Wikipedia entries.

» Although plenty of entries need help, consider focusing on specific biographical areas, such as women's history or diverse artists and scientists. Focusing on people tends to connect students more with the research they are conducting. 


\section{Building a First Year Information Literacy Program: Best Practices and Sample Lesson Plans}

\section{Other Considerations and Thoughts on Teaching First Year Information Literacy}

\section{Universal Design and Accessibility:}

Universal design and accessibility are about inclusion and a focus on a holistic approach to instruction for all types of learners. The conversation around accessibility has historically focused on individuals' disabilities and challenges, but modern instructional-design methods take into account how people learn. Today, universal design and accessibility are about understanding motivation, cognition, and communication - how an individual achieves those goals - and situation. Whether a student's disability is temporary or permanent, universal design and accessibility strive to introduce ways to make learning attainable for anyone in any circumstance. Consider the following:

- Ask questions to make sure information is being transferred and to see if students need more time to process the information.

- If you are showing websites, check the website beforehand and make sure the instructions are clear. Clarify what website students should be going to by writing it on a whiteboard or having a handout prepared.

\section{Equity and Access:}

Not all students have access to a computer outside the library, a laptop to bring to class, or internet at home. How can you teach these students to access resources outside of the classroom? The library may be able to help address these issues:

- Does your library have laptops or a wifi hotspot for students to borrow?

- Can hours be expanded to accommodate students who work during the day and take classes at night?

Collect answers to these questions through surveys or focus groups to make informed decisions to facilitate possible learning opportunities for all students.

\section{Digital Learners:}

A lot of the activities listed in the lesson plans above are for in-person learning. If there are online programs at your school, consider holding online meetings to meet distance students' research needs or design digital badges to reward their learning progress. A digital-badging system can provide incentives for both in-person and online learners, and may specifically help online learners focus on their learning progress in a decentralized online environment.

Explore the ACRL Digital Badge Interest Group for more ideas or information about digital badging.

\section{C CREDO}




\section{Building a First Year Information Literacy Program: Best Practices and Sample Lesson Plans}

\section{International Students:}

Do you have a plan for supporting international students' research needs? One idea is to offer a series of drop-in workshops or embedded consultations with the Office of International Student Services to support students who are not used to American-style research, resources, and expectations. This can help you build rapport with these students and further promote the library's resources.

\section{Teaching-Faculty Collaborations:}

Information literacy workshops should be developed collaboratively with teaching faculty to help facilitate the learning process for students. Many times, faculty want librarians to take control of the classroom without their input. However, working with faculty to scaffold these workshops can strengthen content, learning, and IL integration in the class. Try these ideas to increase collaboration with faculty:

- Build a learning community for teaching faculty to learn more about the pedagogies of information literacy. These professional development opportunities can help strengthen the relationships between librarians and teaching faculty.

- Work with faculty to conduct curriculum mapping-identify course knowledge and objectives to align them with information literacy skills. 



\section{Using Assessment to Enhance Teaching and Learning in the FYE}

By Ray Pun, First Year Student Success Librarian, California State University, Fresno

\section{(숭 Summative Versus Formative Assessments}

In this section we will define summative and formative assessments, when each is appropriate to use, how they measure students' learning abilities, and how you can best gather this data for meaningful use.

In short, formative assessments occur during the learning process, while summative assessments measure students' overall attainment of knowledge, usually at the end of a course.

Formative Assessment

The goal of formative assessment is to check students' learning and understanding in a single session and inform them of their learning progress. This can be achieved in several different ways:

- Providing instructor feedback on student assignments

- Assessing student understanding through a short quiz or writing assignment

- Encouraging students to ask questions

\section{Summative Assessment}

Summative assessment evaluates a student's performance during a course, using a formal grading scale. Some techniques which require students to apply what they've learned in the class include "low learning" assignments such as:

- A final capstone project

- A midterm/final exam

- A research paper

\section{Both assessment styles:}

- Help define your learning outcomes and goals

- Increase student learning, engagement, and motivation

- Gather feedback and improve your teaching practices and assignments

\section{Below are some example activities you can apply in your instruction independently or collaboratively:}

Formative Assessment Activities

Have students draw a concept map or mind map of their research topic and think of keywords associated with this topic

Have students write a one-minute reflection after a library instruction and share these reflections with another peer

For research topics, have students conduct research on their own before class and during class show them how they can improve their research using library sources. Make sure to ask questions about their topics to gauge their understanding

\section{Summative Assessment Activities}

Attend students' final research/capstone project presentations and evaluate their work

Collaborate with faculty to assess students' bibliographies, work citations, and references in final papers

For semester-long research papers, evaluate students' proposals mid-semester to gauge progress and create a final exam based on IL skills to assess students knowledge and proficiency 
Using Assessment to Enhance Teaching and Learning in the FYE

\section{Qualitative Versus Quantitative Data}

Before you begin any assessments, it's important to establish goals to help determine what type of data you should collect. Applying assessments based on your goals and collecting the relevant data may give you more understanding of your own teaching practices, services, and students' learning abilities.

\section{Questions to consider:}

Do you have research questions you would like to answer?

Do you have learning theories you want to prove?

Do you want to create new theories?

There are two types of data you can collect during and after your assessment activities, qualitative and quantitative. Using the method that best fits with your goals is important to putting your results to best use.

\section{Qualitative Methods}

Qualitative data is used to present how students can apply, synthesize, and evaluate what they've learned. This may help you gain deeper insight into your students and enrich their experience and learning. Below are several qualitative activity ideas, generally viewed as formative assessments as they can inform students of their learning while engaging them.

Qualitative data is based on responses and feedback comprised mostly of sentiments, words, or reflections, while quantitative data is based on statistics, numbers, and figures that are quantifiable.

\section{Drawing Activities (best done in the beginning of a workshop)}

Draw a library map, a think-pair-share activity.

- Students draw a map of the library from memory and share drawings with peers in the class.

- The drawings will reinforce the students' understanding of the library and they may learn from their peers about the services they didn't include on their own maps.

- Following this think-pair-share technique, show them the real map of the library and explain the various areas and services more in-depth.

\section{Draw the library's website}

- Students draw the library's website and then share with their peers.

- Observe how they draw and talk about the website. You may hear conversations from students that surprise you! Make sure to take notes for your own research and assessment.

- Review the website with your students, reinforcing their memory about the website's resources. 


\section{Using Assessment to Enhance Teaching and Learning in the FYE}

\section{Student Perspective Activities}

- Focus groups are one of the best ways to collect valuable, qualitative insights into your library services and programs. If you don't have one already, consider creating a student advisory group. A student advisory group, particularly composed of first year students, can help reveal what is or isn't working. (See helpful success tips below!)

- Open-ended questions may be more feasible if student groups aren't an option. Ask probing questions at the end of class to prompt students to share library experiences with you.

- Open-ended user-experience surveys (as opposed to shorter, quantitative surveys described below) are another option for gathering feedback. These can be passed out during focus groups or during instruction sessions.

- One-on-one interviews can also be conducted with students who may not be comfortable sharing their thoughts openly in groups.

\section{Tips for Successful Student Focus Groups:}

$\checkmark$ Recruit students from your network - i.e. IL classes, student assistants, word of mouth, teaching faculty, or advisor recommendations.

$\checkmark$ Offer incentives for all participants including free refreshments.

$\checkmark$ Create groups of 5-8 interviewees to spark good conversation while allowing a chance for everyone to participate.

Keep sessions to an hour and ensure every participant has an opportunity to answer your questions.

Hold a few sessions over the course of the semester to track students' thoughts and challenges.

Use sessions as an opportunity to test new IL activities with students. See how they respond and collect feedback they provide to help shape your own instructional strategy.

\section{Quantitative Methods}

Quantitative or measurable methods of evaluation surface what students' have learned. This evaluation method focuses on knowledge and may produce clearer, more objective results. Some examples of quantitative data collection activities are:

\section{Surveys}

The most common method for collecting quantitative data, surveys can range in length from very short (one or two questions) to exhaustive. For first year students, consider keeping surveys short and using easy-to-use 


\section{0}

survey builders such as Google Forms or Survey Monkey. These can be distributed either at the beginning or end of a library workshop, depending on what you are attempting to measure.

If you plan to conduct a summative assessment, you may want to create and distribute comprehensive surveys to assess students' learning progress in skills such as search techniques and ability to use library resources.

\section{Micro-assessments}

These mini-surveys can be used to quickly measure your users' sentiments on a particular micro-topic. For example, if you plan to offer research services in a particular part of the library, have students fill out a twoquestion survey to see if they would be interested in receiving research services in this location. Consider using "emojis" as a likert scale from 1 to 5. Today's students tend to respond better to this type of scale, creating better engagement and a better data sample.

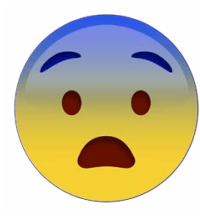

1

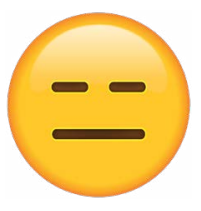

2

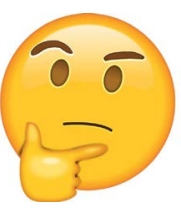

3

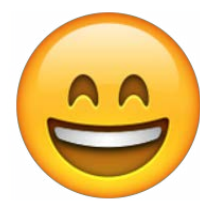

4

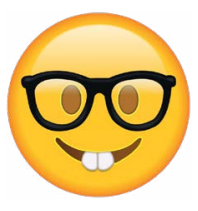

5

\section{Mixed Methods Approach}

You can use both qualitative and quantitative evaluations in a single study, applying one method after another, or concurrently. For example, in information literacy assessments, you can apply the quantitative method, offering a pre- and post-workshop survey to assess students' IL learning. Using the qualitative method, meet with students in focus groups or conduct in-depth interviews. Ask open-ended questions about their impressions of the library and their own skill-development to gather further data and gain a deeper understanding of your students' learning. Using both methods can provide you with a complete assessment from students' knowledge to application of their level of understanding. 


\section{Using Assessment to Enhance Teaching and Learning in the FYE}

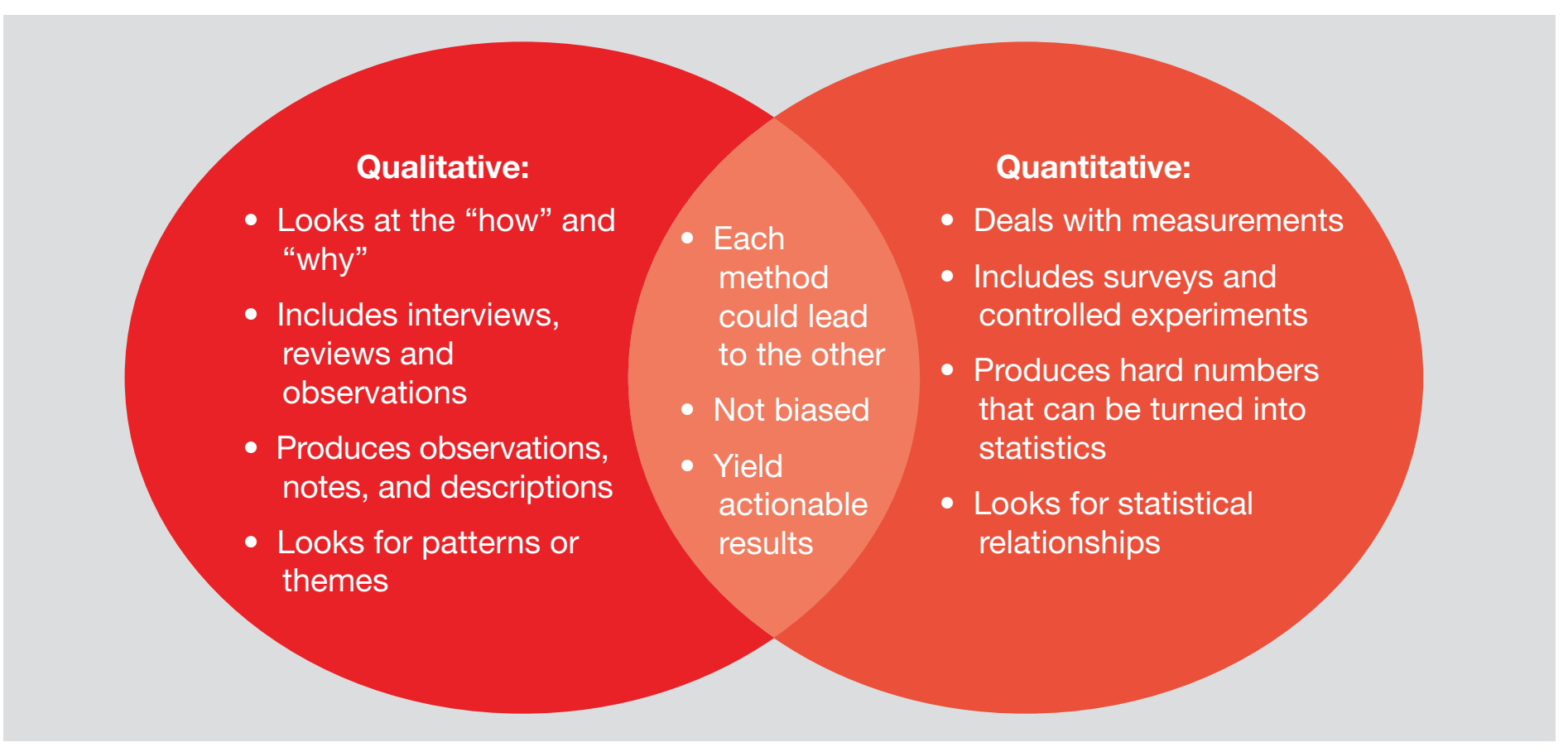

\section{(1) Caution}

\section{Data Privacy and Third-party Tools}

Be mindful of students' data, particularly relating to private and sensitive information such as their background or student ID numbers. As educators, we have a professional responsibility to ensure the safety of our users, including their information and data. Learning analytics tools should always be approached cautiously. While helpful, monitoring students' learning behavior with external tools can be very controversial, costly, or challenging to apply.

\section{Human Research}

If you are conducting research for scholarly activities, check your school's institutional review board (IRB) policies for approval as your students are considered human subjects. Any information you plan to disseminate in a publication or conference presentation should be stated in your consent form or survey for your student subjects/interviewees. Your IRB Office may have waivers or consent forms for you to use.

\section{Using Assessment Data to Market Library Services}

While collecting and analyzing data is important for improving and enhancing your instruction strategies, to get the most mileage out of your assessments, showcase your results and draw attention to library successes.

\section{C CREDO}


Using Assessment to Enhance Teaching and Learning in the FYE

\section{How can you communicate and share assessments most effectively with the campus community and administrators?}

\section{Present in formal and informal meetings}

Give debrief sessions to fellow librarians and faculty, highlighting assessment results and outlining next steps. This may open doors for future collaboration and build relationships with colleagues from other departments. Share findings with your student advisory group as well. These sessions can encourage a community of practice around learning assessments at your institution, and the library's role in supporting them.

\section{Get creative! Share using infographics, posters, social media, and more}

Using posters, fliers, and infographics is a great marketing strategy to visually communicate your assessment results and promote your existing services and resources. Fliers or posters can inform students, faculty, and campus administrators courses librarians are involved in. Share students' positive feedback on social media and in visual aids - be sure to get their approval beforehand.

\section{Check out a few infographic sites to get started for free at the basic level:}

$\checkmark$ Infogram allows you to customize and create infographics, maps, and other visuals

Piktochart creates brochures, presentations and infographics with an easy-to-use interface

$\checkmark$ Canva is an intuitive tool for graphic design

\section{Publish Findings and Present at Conferences}

Beyond using assessment results to communicate the library's value and improve your IL program, you may want to share your findings with other library and education professionals, either through publications or in conference presentations.

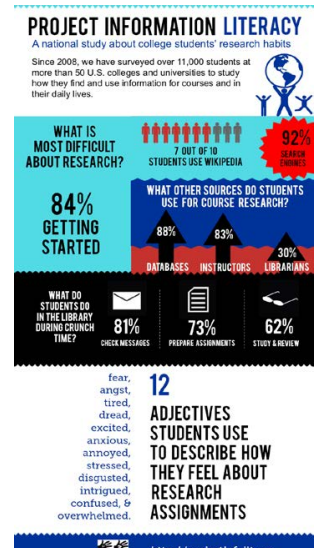

\section{Think beyond assessment for the sake of assessment.}

The general practices and evaluation techniques in this chapter can be used in most library settings to help improve the effectiveness, impact, and value of your library's instruction program and you as an instructor. As assessment continues to grow in interest from campus and community groups, more opportunities and resources will arise for libraries and librarians to support deeper student learning. 


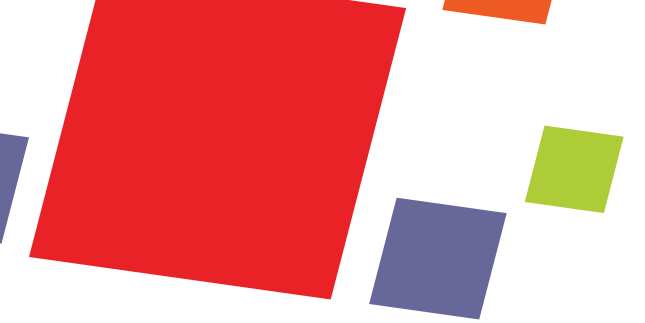

\section{C}

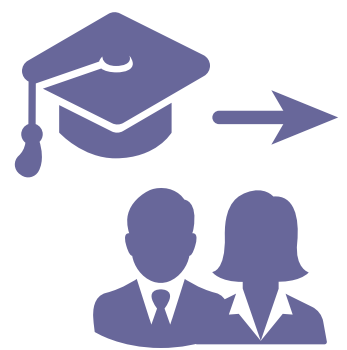

\section{Chapter 5: Student Engagement}

After designing an information literacy program, collaborating with faculty, and building your assessment strategy, it's fun to switch gears to one of the most exciting aspects of the FYE: student engagement. Cultivating strong relationships with your students is a high-impact practice that can positively affect everything from retention to graduation rates. As a central fixture at most campuses, the library is uniquely positioned to offer engaging experiences and promote student growth and development. In this chapter, we'll cover three themes for building student engagement: health and wellness, learning engagements, and inclusivity. 


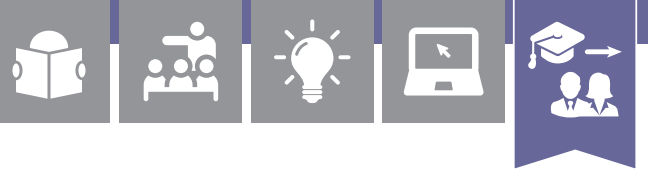

\section{Fun Times in the Library: Fresh Ideas for Engaging Your Students}

By Ray Pun, First Year Student Success Librarian, California State University, Fresno

\section{Three Student Engagement Themes}

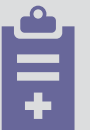

Health and Wellness: From therapy animals, to gentle exercises, to meditation sessions, these activities can help students de-stress and recharge when visiting your library.

国

Learning Engagements: Opportunities to promote important skills for student success and retention using collaborative learning activities.

Diversity and Inclusion: Practices for creating a helpful, safe, and comfortable environment supporting all activities and experiences.

\section{Health and Wellness}

The first year of college is stressful. Students are in a new environment, trying to acclimate to the rigors of higher education, and just when they start to settle in, midterms hit. Offering programs to help students approach these challenges with a calm and focused mindset can help you forge a lasting bond. Below are a few creative ideas for connecting with your students:

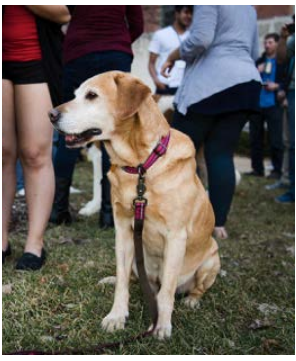

Therapy animals: Many libraries today are partnering with local therapy animal groups to organize animal visits to the library. One benefit of this highly-effective, exceedingly popular program is it's often free (other than printing posters).

Note: Sometimes people express concerns about allergies or a fear of dogs. Make sure you have signage to help affected folks know which areas of the library to avoid.

Building mental and physical strength: Meditation sessions, often offered by a trained specialist from your health services program, can teach breathing techniques and basic yoga moves to help students de-stress. These types of activities may improve students' self-esteem and confidence - which is especially helpful during finals week! You can also partner with your physical therapy programs to bring in students trained to provide massages, or rent massage chairs to alleviate students' stress. Don't forget to provide light refreshments like fruits or other healthy snacks.
Have you thought of partnering with your Office of Student Health Services? They may be able to provide you with resources, services and other programs to share.

\section{CREDO}




\section{Fun Times in the Library: Fresh Ideas for Engaging Your Students}

By Ray Pun, First Year Student Success Librarian, California State University, Fresno

Silent discos: Dancing and listening to music is another technique used to reduce academic stress. To help students loosen up during high-stress situations like mid-terms and finals, the library can host a silent disco. Students listen to music through their headphones and can dance in designated parts of the library without disrupting the quiet. Take this activity to the next level by recruiting a DJ or purchasing headphones with built in bluetooth abilities which sync with a computer/tablet so everyone can hear the same song.

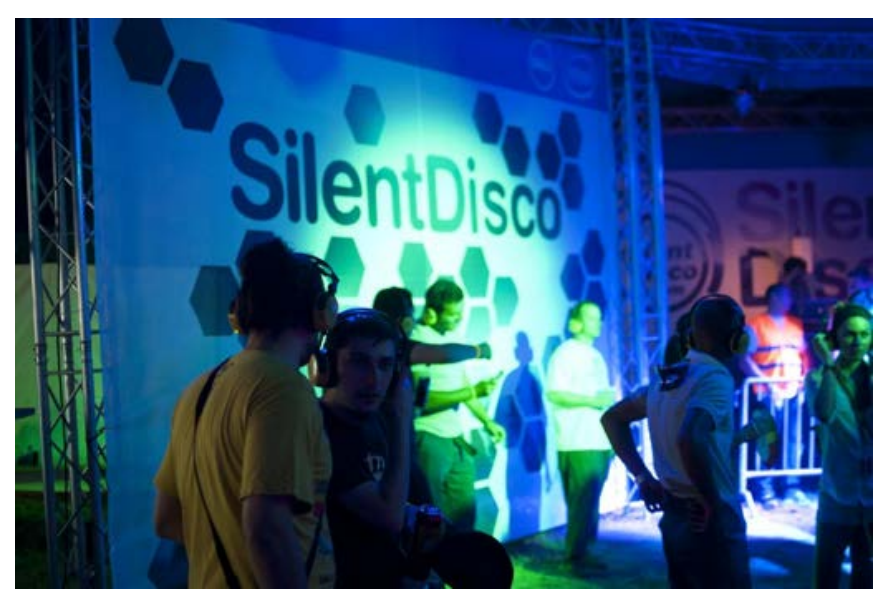

If you're still having trouble picturing what this looks like, watch students at University of WisconsinMadison get down during finals week.

Crafternoons and artistic activities: When students need a break from studying and writing papers, engaging other parts of their brains can provide a healthy and refreshing escape. Paint nights are a popular public library event that can easily be brought into the academic space. If you don't want to commit to painting, coloring or collage/scrapbooking are other art activities to try.

Check out

New York Public

Library's free

and printable

coloring books!

Tip: You can either provide art supplies or collaborate with your art department to facilitate the activity.

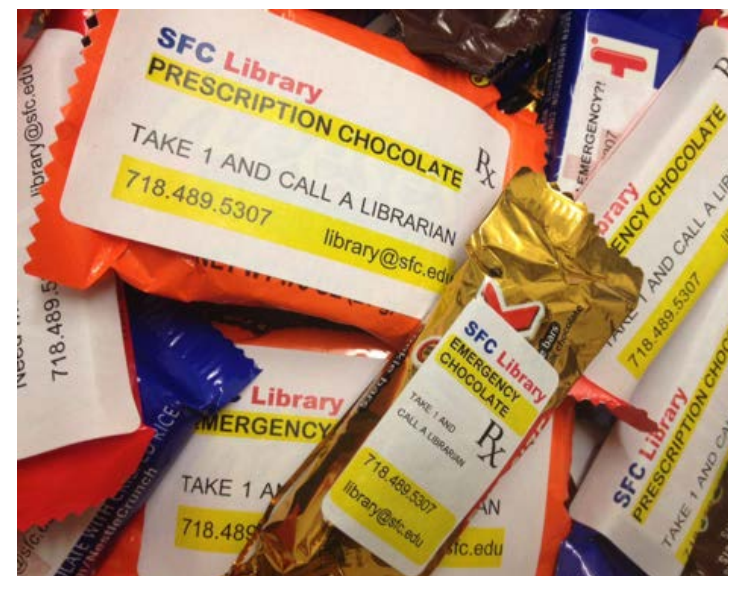

Reference desk giveaways: Outside of gravity, few forces in the universe are stronger than the attraction between college students and giveaways. During orientation, midterms, and finals, stock your reference desk with items your students will love and can simultaneously promote library services. Some items could be stress balls with the library's logo, pens, pencils, or USBs. Offering postcards to students to write to their families and friends is another way to help build rapport with your users. St. Francis College creatively offered "emergency chocolate", listing the library's email address and phone number on the wrapper.

\section{C) CREDO}




\section{Fun Times in the Library: Fresh Ideas for Engaging Your Students}

By Ray Pun, First Year Student Success Librarian, California State University, Fresno

\section{祭 Learning Engagements}

When developing engagement programs, look for student collaboration and innovation opportunities. If you refer back to previous chapters of this guide (Collaboration and Information Literacy in particular), you'll find most activities discussed aim for student engagement in addition to desired academic outcomes. This is largely due to our efforts to align with the Association of American Colleges \& Universities' highimpact practices (HIPs); teaching and learning practices fostering student retention, engagement, and success. Some examples of HIPs include first year seminars, collaborative assignments and projects, and service

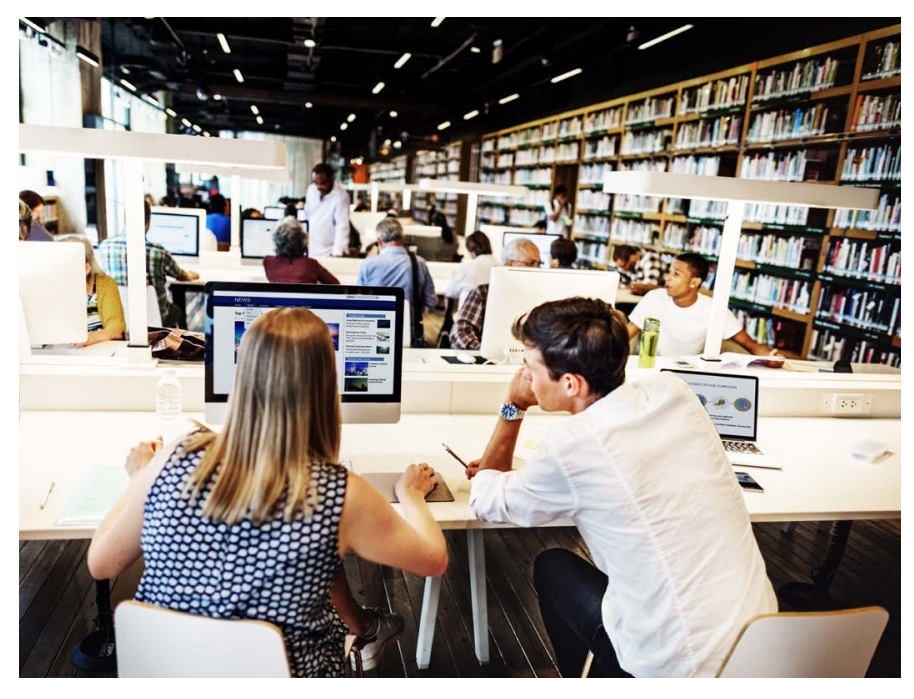
learning. These specific activities are often designed and implemented by teaching faculty, however, plenty of opportunities exist for librarians to get involved. In this section, we'll focus on two examples of innovative learning engagement activities linking several HIPs: hackathons and edible book fairs.

\section{Hackathons}

Hackathons (sometimes called hackfests) are a popular and growing trend on campuses around the world. Students come together to share common goals, visions, and interests in creating devices, tools, or products with tremendous potential for creating social change. From computer science, to business marketing, to art and design, to education, to health and human services, hackathons are marathon events bringing together different people to create usable software, apps, or systems.

These events encourage and foster entrepreneurship, experiential learning, engagement, and risk-taking. The library can participate in a number of ways, hosting and organizing events with different campus partners and student groups and providing programming languages and design skills resources for participants to apply within their products.

Disclaimer: One doesn't need to be a programmer to organize or participate in these events. The interdisciplinary nature of hackathons makes them open to everyone! 


\section{Fun Times in the Library: Fresh Ideas for Engaging Your Students}

By Ray Pun, First Year Student Success Librarian, California State University, Fresno

\section{Steps for organizing a successful hackathon}

\section{Choose a theme}

\section{Potential themes include: \\ - Education \\ - Health and wellness \\ - Accessibility \\ - Environmentalism and sustainability \\ - The social good \\ - And more!}

Once you have a theme, identify which library resources will best complement participants' work.

2. Identify a space - where students can work in teams and access technology and library resources needed to complete projects.

3. Pick your partners - this is a collaborative undertaking, involving both outside parties and students. Reach out to relevant departments, student life, and any local businesses who may want to act as sponsors. Include student groups to give them the opportunity to gain realworld experience organizing events.

4. Promote to students - the better the turnout, the better the experience. Market to your student groups/clubs who might be interested in your theme. Different themes may appeal to different groups. For example, the forestry department may not traditionally participate in a hackathon, but if the theme is environmentalism, they may like to join.

5. Don't forget the first years! - this is a great way to show newbies the interconnectedness of the institution, and get them to connect the dots from the classroom to the real world. Give them some extra support if needed so they don't get lost in the shuffle.

6. Provide food and research help - make sure students know you're available on the day of the event to assist with the project and food will be provided. 


\section{ข}

\section{Fun Times in the Library: Fresh Ideas for Engaging Your Students}

By Ray Pun, First Year Student Success Librarian, California State University, Fresno

\section{Edible Book Fairs}

Edible book fairs are fun events where participants create and transform food into a favorite book or book title. These activities can increase students' engagement with reading materials and the library, allowing them to creatively showcase a theme in their book through baking. Your staff can participate as well, building a sense of camaraderie and competition, and showcasing the library's services and creativity. Offer prizes and refreshment to encourage participation, excitement, and promotion for future events.

Tip: This is a good opportunity to collaborate with your literature faculty, combining the fair with existing FYE shared reading experiences.

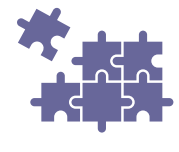

\section{Diversity and Inclusion}

Whether you choose to host a hackathon, edible book fair, or some other collaborative event, HIPs can help you maximize shared resources and strengths to provide unique opportunities for your students.

Students who feel safe and included are more likely to form a deeper relationship with their academic institution. The library plays a crucial role in fostering this relationship and creating a positive experience for them. Make sure your services include these student groups: first generation, non-traditional, student parents, undocumented immigrants, socioeconomically disadvantaged, and historically marginalized/underrepresented populations. Diversity and inclusion are important themes to consider when thinking about HIPs and building relationships with your students.

\section{Rethinking Library Spaces}

The library space is often viewed as a center for activities and engagements, open to any and all groups across campus. Reorganizing physical aspects of the library to provide better and more inclusive services can help you include your entire population's needs and perspectives.

\section{C CREDO}




\section{ข}

\section{Fun Times in the Library: Fresh Ideas for Engaging Your Students}

By Ray Pun, First Year Student Success Librarian, California State University, Fresno

\section{Book Discussions}

Organize book discussions on diversity-related topics. Many colleges and universities already have FYE students read a common book (this falls under the common intellectual experiences HIP). Whether or not this is the case for your institution, your library can promote a reading and host a discussion event with faculty or guest speakers. Book genres can include classic works of literature, or more recent titles. Keep the discussion going year round by creating a list of readings and resources on display and sharing them in a library guide or handout.

\section{Boost Engagement Through Social Media Channels}

Don't forget to promote your engagement activities, events, and spaces on social media to spread the word across campus. When you go "live" on these tools, be sure to ask if students have questions about upcoming events and activities, and offer general library support as well. This is a good way to stay connected to students while supporting their academic needs.

If you have many international students in your school, consider specific social media tools and mobile apps such as*:

\section{$\because$ \\ Wechat WeChat}

This popular app among students from China is a great app for sharing information with students. Create a group and ask students to join it.

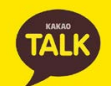

\section{KaKao}

A frequently used mobile app for connecting with students from Korea.

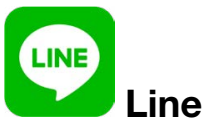

A mobile app for students from Japan, Thailand, Malaysia and other parts of Asia.

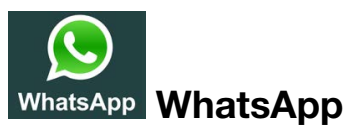

An internationally used app to connect with students from around the world.

*This is only a partial list; be sure to research different groups of students and the apps they use.

Student engagement doesn't have to rely on giant events or costly giveaways. The most important factor is students feel welcomed and supported at their institution. Diversity, inclusion, and a culture of collaboration all help accomplish this. While it is certainly more difficult to assess the impact of engagement initiatives than, say, information literacy, the impact of cultivating strong student relationships with the library and institution can be seen in increased retention and GPAs and is worth the time and effort.

\section{C) CREDO}




\section{$\frac{C}{\mathrm{C}} \mathrm{C}$ CREDO}

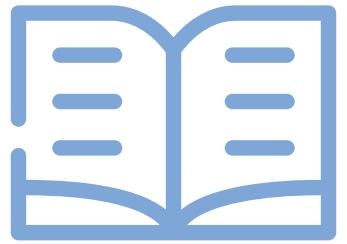

\section{Case Studies}




\section{Starting Off on the Right Foot}

\section{Proven Cases of Successful Orientation Programs}

In this section we will look at three institutions who have found innovative solutions to address some of the challenges of building an effective library orientation program. Orientation is an exciting time on campus, and building a good relationship with new students out of the gate is an important step to starting the year off on the right foot.

Begin the year with these actionable tips to help you expand your reach, raise awareness of library services, and deepen interactions with students!

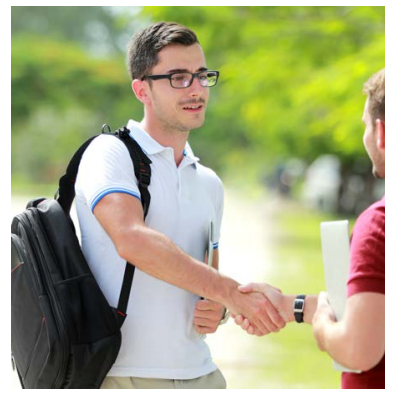

\section{Part 1: Being In Two (or More) Places At Once}

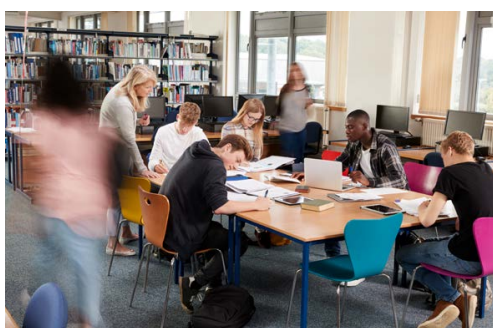

A common challenge with librarians, especially during orientation is the number of incoming first year students far exceeds the number of librarians available to provide meaningful instruction in a timely fashion. The semester moves fast, and if librarians aren't able to reach all new students when they arrive, students may develop bad habits, or miss out on resources that could have helped their research assignments.

Christina Holm, Instruction Coordinator and Ashley Hoffman, eLearning Librarian at Kennesaw State University found a solution to this challenge by coordinating with mandatory first year seminar classrooms to broadcast a live webinar into multiple rooms at once. Students were able to interact with librarians during the webinar using a mobile polling app. Providing timely and relevant information about library resources and being able to engage with students in real-time improved student outcomes and gained faculty buy-in-and nobody had to miss out!

Previously, only $35 \%$ of students received an orientation, and many of these sessions couldn't be scheduled until $2 / 3$ of the way through the semester. After implementing the webinar program, participation rose by over $100 \%$ and students received their orientation in early part of the semester when the instruction would make the biggest impact. In addition to standardizing the orientation curriculum, librarians reported improved interactions with students. Students who attended saw higher GPAs and increased retention. When it was all said and done, a team of just four librarians was able to reach over 3,500 students in the fall of 2017 alone.

\section{Part 2: The Personal Approach}

Many libraries have adopted a "personal librarian" approach, where each student is matched with a librarian upon matriculation. This helps students see the library in a more personal light, rather than as a large and intimidating institution. While these programs are gaining popularity, a common problem is they are underutilized by students.

A small midwestern private university decided to engage incoming students with a series of introductions to the library as a way of solidifying these important

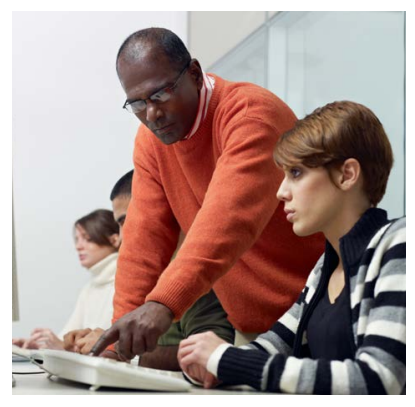
connections. Realizing students weren't responding well to large group instruction during orientation, the 


\section{Starting Off on the Right Foot}

\section{Proven Cases of Successful Orientation Programs}

library adopted a less formal, more personalized approach. At orientation, students:

- Met with their Personal Librarian in small groups

- Visited the library's service spaces

- Received a tour of the library from a student worker

The library collaborated with Student Life to ensure these events were a part of their calendar, and recruited student leaders to participate in the welcoming events.

Survey data indicated students responded well to this low-pressure, welcoming style-but it didn't stop there. Over the course of the year, Personal Librarians continued to reach out to students who attended the orientation, encouraging them and letting them know about available library services.

The librarians, having started their relationships with students with a more personalized approach, saw an increase in student engagement with the library, making more appointments with their Personal Librarian and participating in other library programs.

\section{Part 3: Tour de Force}

Coming up with fresh twists on the standard library tour is challenging, but one state university in Texas found interactive games translated into increased usage of library spaces. The library engages with students almost immediately, participating in on campus Move-In Day, then offers students a chance get to know the library (and win prizes in the process) with activities like:

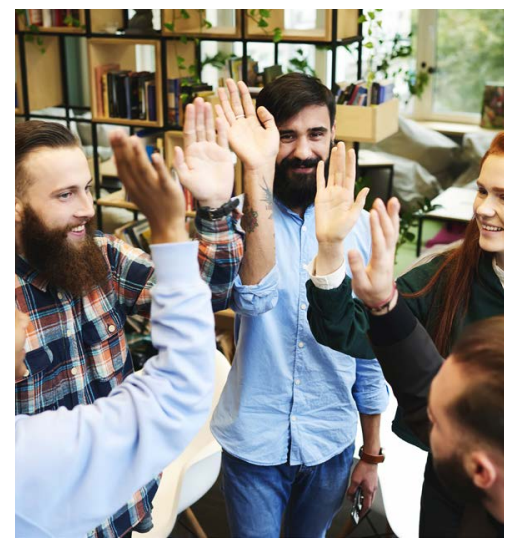

- Library Poker: seven stations around the library offer cards, which students accumulate into winning hands to qualify for prizes

- Selfie Tour: students stop at locations marked throughout the library to learn about services and resources and post selfies at each spot to Twitter and Instagram

- Library Lovers' Board: following an open house event (that included small prize giveaways and food), students and faculty were given the chance to write what they love about the library on a Post-It note and stick it to a large board

All of these activities helped students get excited about meeting the library staff, seeing the facilities, and learning how the library could help them throughout their academic career.

*These case studies feature topics discussed in submissions to the 2018 FYE Innovation Awards, sponsored by Credo and Case Western Reserve University.

\section{C CREDO}




\section{Teamwork Makes the Dream Work: Bringing the Campus Together Around Information Literacy}

Information literacy works best when it is applied across multiple settings and consistently to all students. That being said, this isn't something a library can do on its own. The following case study features libraries and librarians who have forged diverse partnerships to cultivate stronger IL skills across the first year experience.

\section{Building Relationships for Consistent Instruction at Dickinson College}

\section{Dickinson}

College
Dickinson College's Waidner-Spahr Library attributes the success of its IL program to the spirit of continuous and collegial collaboration between the library and its campus partners. In particular, they have focused on three strategies:

Teaching FYE faculty how to embed IL in their assignments

Working with administrators to optimize instruction

Using the library space to host events and entice new opportunities

\section{Teaching the Teachers}

In partnership with the Writing Center, the library co-sponsors a workshop for FYE faculty, during which they discuss best practices for writing and research. One concept they brought to the faculty was "stealth lessons" in IL. For example, early in the semester students were required to read a scholarly article and answer questions about

it. The catch was students had to retrieve the article on their own (after reading instructions or watching an online tutorial), rather than

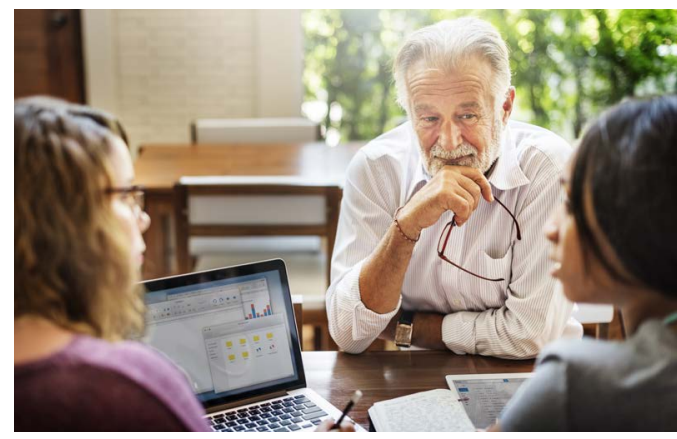
having it handed to them. This simple change in pedagogy has supported the library and helped students by acclimating them to the library's website, providing hands on research experience, and allowing librarians to focus on more advanced topics during in-class sessions.

\section{Reaching Out to Administrators to Enhance Learning}

With academic integrity being of the utmost importance to the college, the Waidner-Spahr Library was asked to worked with the Provost's office to teach academic integrity and plagiarism avoidance via an online tutorial required of all new students. Following this successful engagement, the library teamed up with Academic Advising to give remedial help and additional support to struggling students. Some other relationships that have yielded meaningful results for the library include:

- Academic Support Offices: working to improve instructional librarians' teaching styles and learning spaces to better accommodate all students

- Race and Ethnicity Center: helping staff members recognize and avoid implicit bias

- Disability Services: broadening accessibility of spaces and resources for all users

\section{C) CREDO}




\section{Teamwork Makes the Dream Work: Bringing the Campus Together Around Information Literacy}

\section{A Hub for Collaboration}

The library at Dickinson is a hub where student success across academic divisions and extracurricular activities is highlighted, helping the building function as an important gathering space. Students from all class levels can participate in library-sponsored events such as awards ceremonies, poetry readings, internship panels, and art displays. These outreach efforts maximize student exposure to library services while keeping the library staff engaged with the community.

When surveyed about the effectiveness of library instruction in the First Year Seminar, 95\% of faculty reported that students applied some or all IL skills to the extent expected.

\section{Library Leadership: Actively the FYE at Bryant University}

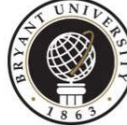

Bryant U N I VERSITY

Bryant University is known for its rigorous academic programs, first year student experience, emphasis on students problem-solving in creative ways, and a campuswide focus on student success. The Douglas and Judith Krupp Library embraces this with its own culture of flexibility, experimentation, and collaboration.

\section{Innovating Within the Library and With Campus Departments}

In 2012, Bryant University launched the First-Year Gateway Program. When the library was chosen to help identify the skills deemed most important for graduates, librarians advocated for IL to be included as one of the program's five key learning outcomes. This proved an essential framework for what came next. The library helped create a Writing Workshop for all first year students, establishing an embedded librarian in each section of the course, and enabling the library to see all first year students within the course.

\section{Forging Partnerships for Student Success}

Bryant developed its summer bridge course with input from the Associate Director of Library Services, an E-learning specialist, and subject matter experts from Undergraduate Advising and the Academic Center for Excellence. The goal was to build an engaging online experience that would help transition incoming students through issues such as university jargon, navigating the learning management system, joining a scholarly community, and more. As the program has progressed, different campus groups have been included to provide continual assessment, improvements, and updates.

When the library extends its reach across campus, everybody wins. Faculty learn about more and better resources for their discipline; students become more integrated into the academic community while building essential IL skills; and institutional goals like retention, graduation, and employability all benefit too.

\section{C) CREDO}




\section{A Comprehensive Q\&A with Lisa Hinchliffe}

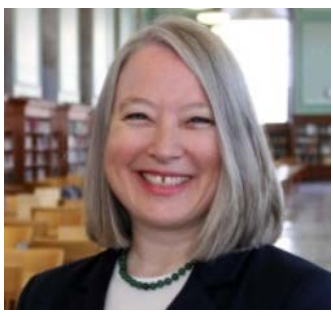

Lisa Janicke Hinchliffe, Professor/Coordinator for Information Literacy Services and Instruction at the University of Illinois at Urbana-Champaign, joined us to answer some questions relating to her forthcoming study, Predictable Information Literacy Misconceptions of First-Year College Students. In this interview she discusses how a better understanding of student misconceptions around information literacy could lead to more effective FYE programming and better research assignments, and shares her hopes for further areas of inquiry into this topic.

Your study addresses first-year students' misconceptions about information. How do you define misconceptions?

LH The study used a definition of misconceptions based on the explanation offered by Wiggins and McTigue in their book Understanding by Design, in which they say that "such misunderstandings, as opposed to confusion or inattention, typically flow from prior experience and a plausible inference based on that experience." In other words, a misconception is a belief held by students that is incorrect but is held to be true based on prior experience. We also distinguish misconceptions from things not-yet-known. Lack of knowledge is not a misconception though it is an absence of understanding.

\section{What were the most significant misconceptions you found, in terms of changing how librarians approach information literacy education?}

LH At this point we do not yet know how librarians will use the results of our study. I am looking forward to hearing feedback from the library community about which of these misconceptions are most problematic or prevalent as well as how librarians use the results of the research. This is really just the beginning of this line of research.
"This is really just the beginning of this line of research."
"I would ...

recommend

that instructors

use [the

research] as a

lens to reflect

on their own

experiences as

instructors and

on their lesson

plans"
Did you notice any different assumptions for traditional first year students vs. non-traditional first year students?

The research study did not probe that aspect of this topic but it would be a great follow-up study. In many ways, this research raises more questions than it answers. There are many possibilities for studies to build upon our findings.

Your work looks at first-year students overall, but how can an instructor find out what misconceptions are held by a particular student or class?

LH

Rather than using this research as a diagnostic tool for individuals, I would instead recommend that instructors use this as a lens to reflect on their own experiences as instructors and on their lesson plans. In particular, if you are teaching a specific concept or skill and students struggle or are resistant, is that possibly explained by a misconception? If so, it might be necessary to create a scaffolded set of learning experiences that first, has students encounter their misconception and then, introduces the next concepts.

Also, instructors should review their materials to make certain that they are not inadvertently teaching or reinforcing misconceptions. Here's an example with the misconception that 'first year students believe that all library sources and

\section{CREDO}




\section{A Comprehensive Q\&A with Lisa Hinchliffe}

discovery tools are credible.' I wonder if the emphasis on evaluating Internet-based information resources inadvertently led students to believe that library resources were already evaluated for credibility.

\section{You state that, "correcting misconceptions and establishing a foundation of conceptual} understandings may be a precursor to Framework-based information literacy instruction." What would this precursor look like?

LH Some of the concepts in the ACRL Framework for Information Literacy in Higher Education are quite complex. Students may not be ready to engage that complexity if that foundational knowledge they have is flawed by misconceptions.

So, for example, if a student holds the misconception that 'research is a linear, uni-directional process,' then we can imagine them struggling with the concept of 'Searching as Strategic Exploration' that states "searching for information is often nonlinear and iterative, requiring the evaluation of a range of information sources and the mental flexibility to pursue alternate avenues as new understanding develops. " The student will have to give up the misconception in order to learn this frame and then develop skills and abilities that flow from the frame.

Similarly, the same misconception will be an impediment to any instruction that is based on the premise that a student recognizes 'Research as Inquiry,' which states that 'research is iterative and depends upon asking increasingly complex or new questions whose answers in turn develop additional questions or lines of inquiry in any field. ${ }^{2}$

\section{What are the implications of this study for librarian-faculty collaboration?}

As my co-authors and I suggest in the article, librarians might use the list of misconceptions to work with faculty to design assignments and instruction that address first year students' misconceptions about libraries, information access, and the research process. Librarians could also use the misconceptions to open a dialogue with faculty about whether they too observe such misconceptions in learners and if they would add any others to the list.

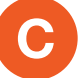

How would one explain these misconceptions to faculty who are unfamiliar with information literacy and how it could help their students?

LH I find that most faculty have an intuitive sense of information literacy even if they don't know the specific term. I would likely start a conversation around the misconceptions by framing it as a discussion about whether they notice students struggling with library research, what do they notice, etc. and then drawing connections between their experiences and the misconceptions.

\section{Are the expectations of higher ed institutions too high with regard to incoming students'} information literacy skills?

나

I am not certain that there is a monolithic set of expectations about skills and abilities. I think the most important thing is to remember that students are students - they are in college to learn and so finding out what they need to learn and creating learning experiences that meet their needs is the best approach. We might wish they knew more but if they don't, they don't. Our role is to teach the students we have, not the ones we might wish we had. 


\section{A Comprehensive Q\&A with Lisa Hinchliffe}

Given that librarians have such limited opportunities for instruction, are some of these misconceptions more urgent to address earlier than others?

L A key part of addressing the misconceptions is not falling into the trap of thinking that as an instructor you can just assert that there is a truth different than what students believe. Students need to encounter the misconception failing them. So, the misconceptions to address earlier are the ones that would impede their learning earlier, i.e., those that would fail them. This will depend on the campus curriculum and so I can't prioritize these in the abstract but would have to be considered in context of the first-year curriculum.

\section{How should research assignments change as a response to this new information?}

Some research assignments inadvertently reinforce misconceptions so the first change would be to revise the assignments to avoid doing that! I think the other change that becomes very obvious is the need to create assignments that have scaffolded learning experiences that allow students to encounter the problems with adhering to the misconceptions and then support them in developing accurate conceptions.

How persistent are these misconceptions? In other words, do you think they will be easy to correct during instruction sessions, or will they require repeated interventions across multiple settings to break through to students?

나

It is difficult to predict how persistent a misconception might be as we cannot control other life experiences that might be reinforcing the misconception at the same time that we are trying to teach to correct it. In general though, changing what someone believes is something that requires repeated engagement in comparison to simply adding new facts or skills that are consistent with things that one already believes.

\section{If librarians are interested in conducting a similar study in their own campus, where should they start? Any recommendations? \\ (C) \\ campus, where should they start? Any recommendations?}

"A key part of

addressing the

misconceptions is not

falling into the trap

of thinking that as an

instructor you can just

assert that there is a

truth different than

what students believe"

LH My co-authors and I provide our focus group protocol in the appendix to our article. They could adapt that protocol to serve as the basis for a general conversation/brown bag lunch or for a local research project - in either case, using the list of misconceptions as the starting point. I am interested in collaborating on research projects that build off of this study and so would be happy to hear from anyone that might like to work together.

\section{Do you anticipate that these misconceptions will continue to change over time?}

That is a great question! I would hope that over time we might be able to see fewer misconceptions but it is of course possible that new ones will emerge. Given open access practices are changing, what is available on the open web and how difficult it can be to determine if a preprint has been peer reviewed, it seems entirely possible that we could see the emergence of misconceptions in this area.

Be sure to read the full article by Lisa Janicke Hinchliffe, Allison Rand, and Jillian Collier, "Predictable Information Literacy Misconceptions of First-Year College Students”, which will be published later this year in Communications in Information Literacy.

\section{OC CREDO}




\section{Improving Library, Faculty and Student Performance through Assessment}

Assessment strategies are becoming more and more important for success in today's competitive environment. Gathering meaningful data to measure how well students are attaining important learning outcomes can be used to help faculty and institutions improve curricular design and effective teaching methods for student learning and performance.

In this case study*, we review how librarians at a large community college in the Midwest used assessment data gathered through their first year experience initiative to measure student progress and improve the quality of instruction provided by librarians and faculty. After the FYE steering community identified which learning outcomes they wanted to track, the librarian created rubrics to consistently gauge student performance using their school's LMS.

\section{5 rules to make the most of your assessment data:}

1) Clearly define learning outcomes

2 Consistently measure and collect data

3 Include the broadest possible sample size for the most accurate results

4 Use results to inform future changes to the program, or to individual instructors

5 Broadcast results far and wide to demonstrate the value of the library

\section{Where to Begin}

Assessment does not occur at random. It's imperative someone (e.g. the FYE steering committee, library leadership, etc.) first create goals and objectives to decide which student learning outcomes should be prioritized, and then design an assessment strategy to measure them accordingly. Of the steering committee's desired learning outcomes, "Uses Information Effectively," was explicitly connected to library instruction. They agreed on four skill indicators:

Developing a search strategy

Using technology

Evaluating information

Using information responsibly

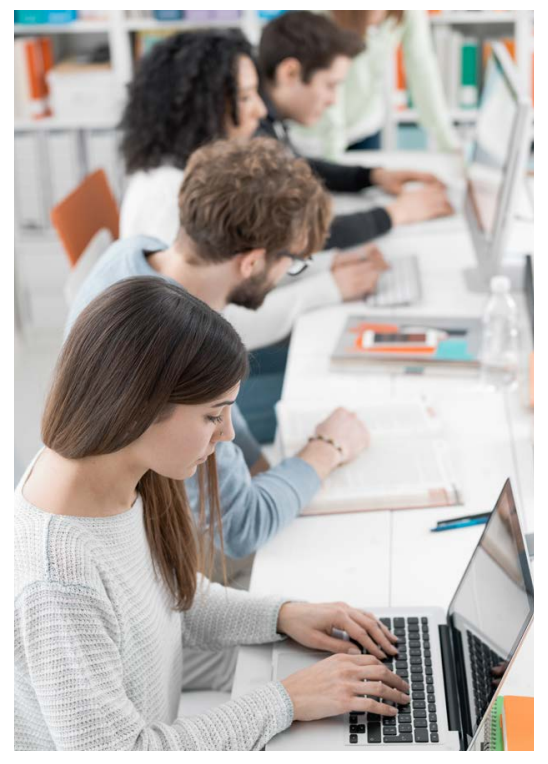




\section{Improving Library, Faculty and Student Performance through Assessment}

\section{Collection and Measurement}

The librarian designed a rubric to assess whether a student "uses information effectively." This included the four performance indicators, each of which could be measured against a benchmark (starting point), two milestones, and eventually a capstone to show the skill had been mastered. They decided the best way to accomplish data collection was through the school's LMS, combined with other course artifacts.

The assessments proved students were benefiting greatly from their information literacy instruction sessions. Additionally, faculty use of library services and requests for instruction have been on the rise since the start of this initiative!

Prior to the librarian-led instruction session, only 4 out of 10 students rated their ability to do college-level research as Good or Excellent; afterwards, this rose to $\mathbf{8 3} \%$.

\section{Putting Data to Use!}

Confirming instruction had a positive impact on student performance achieved the Steering Committee's goals, but the institution decided to take the assessment results a few steps further:

Professional development: The librarian applied for and received a professional development grant to participate in the ACRL's "Assessment in Action Project".

Faculty buy-in and support: Librarians and faculty studied the data to spot areas they could improve for future sessions.

Future improvement opportunities: Data was also analyzed by the FYE steering committee to inform future changes to the program.

Creating a culture of assessment and improvement isn't easy, but the benefits to faculty, librarians, and students are undeniable. This community college library's success was predicated on making their voice heard on the FYE steering committee and assessment committee, clearly defining their goals, collecting data consistently, and showcasing the impact once the numbers were analyzed.

*This case study features the story of one institution discussed in a submission to the 2018 FYE Innovation Awards, sponsored by Credo and Case Western Reserve University. 


\section{Once Upon a Library: How a Storytime Collaboration Helped Build FYE Engagement}

Student engagement activities are often thought of as fun, one-off events, but there are also long-term projects your library can initiate to deepen your relationship with students. In this case study, we examine how a librarian at a mid-size public university teamed up with an FYE faculty member and the campus daycare provider to improve student engagement, teach valuable information literacy skills, and help students meet their service-learning requirements.

\section{Increasing Engagement through Collaboration and Service Learning}

To help students get excited about their academic future, the librarian and FYE professor created a semesterlong service-based project. Community and service-based learning is defined by the AAC\&U as a high-impact practice within the first year experience, so they collaborated with the university's daycare center to get their students involved in the daycare's children's storytime. This project encouraged students to engage with the campus community and reflect on various communication concepts - all while learning library and research skills at every step.

The project had 4 primary steps

for students to complete during

the semester:

$\checkmark$ Introduction to the library: Visit

the library and check out 17-20

children's books, then create an

annotated bibliography for the list.

$\checkmark$ Community participation: Sign

up as a reading volunteer at the

university daycare (optional and

applicable to service-learning

requirements).

$\checkmark$ Familiarization with library

services: Tour the library,

learn about their services, and

receive instruction on creating

an annotated bibliography.

$\checkmark$ Connection and understanding:

Complete a reflective assignment

to better understanding learned

communication concepts.
Reading to the daycare children helped the students gain real-world experience, both in terms of the communication concepts they were learning in class, and in understanding the role of books in lifelong

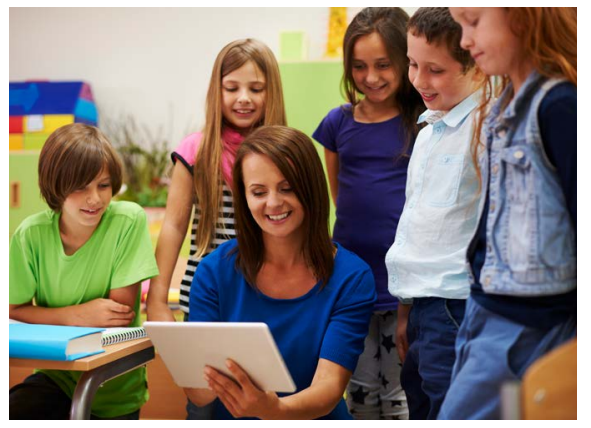
learning. Visiting the library and meeting its helpful staff during the project opened their eyes to the many services provided by the library.

\section{Happily Ever After: Long-lasting Program Benefits}

By the end of the semester, students had formed a stronger relationship with the institution as a whole, and the library specifically through their participation. Many commented about how meaningful they found the project. In addition to becoming more invested in the college, they cultivated valuable academic skills, both of which are considered strong factors in retention and graduation rates. Because students' introduction to the library was such a positive experience early in their academic career, they are now more likely to use its service as they advance.

\section{C) CREDO}





\section{Collaborating Across Campus}

Map out prospective partnerships to benefit your library and students. Click on each building to explore potential collaborative activities.

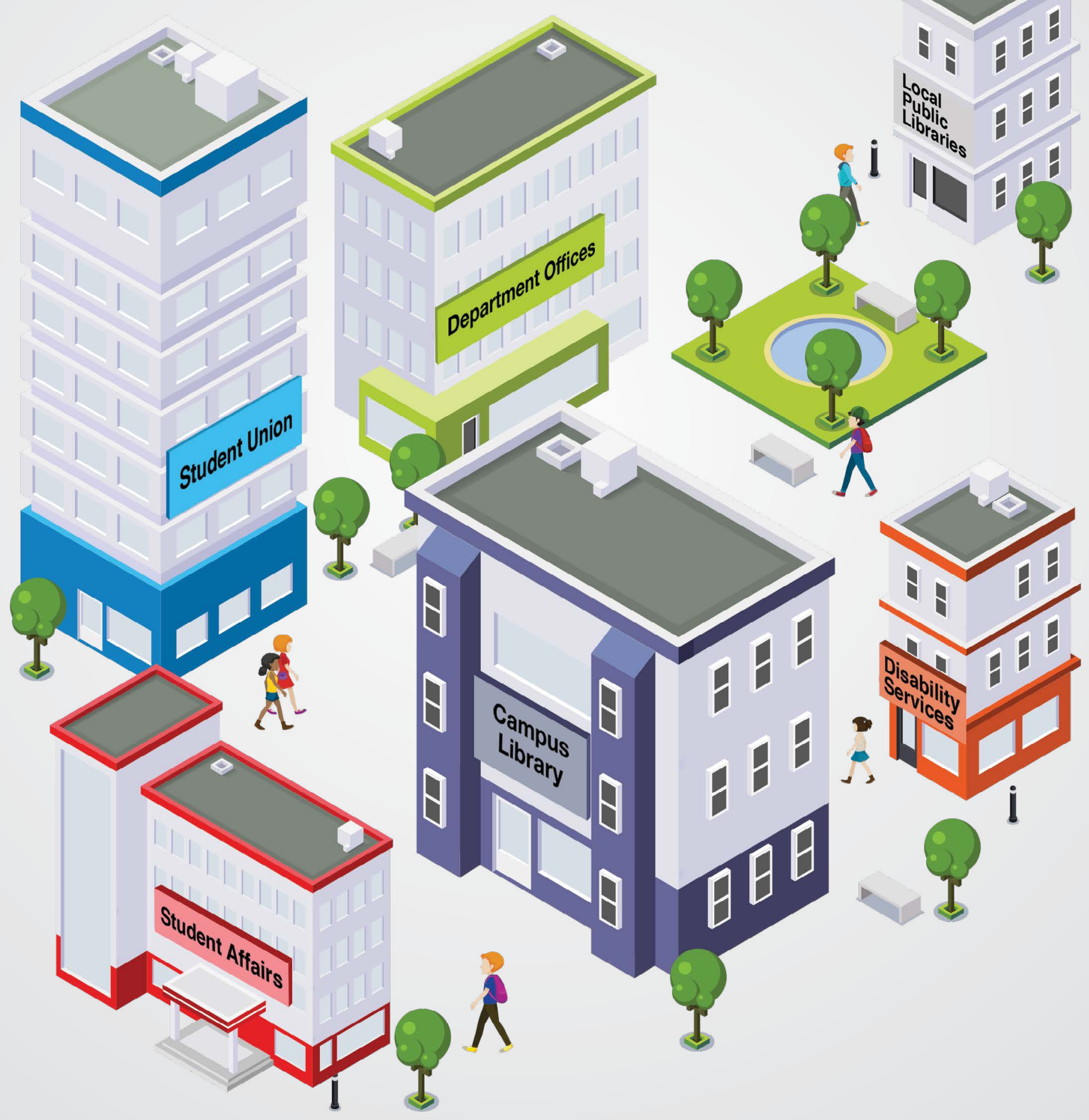

\section{C CREDO}




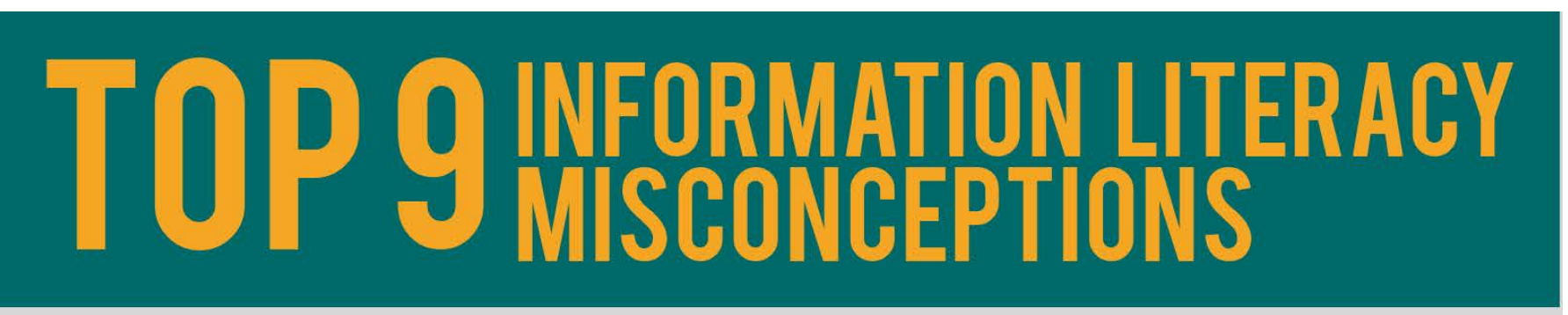

First-year college students believe they are supposed to do their research without assistance.

2 First-year college students perceive the library as only a place to get books or to study.

2. First-year college students believe that all library sources and discovery tools are credible.
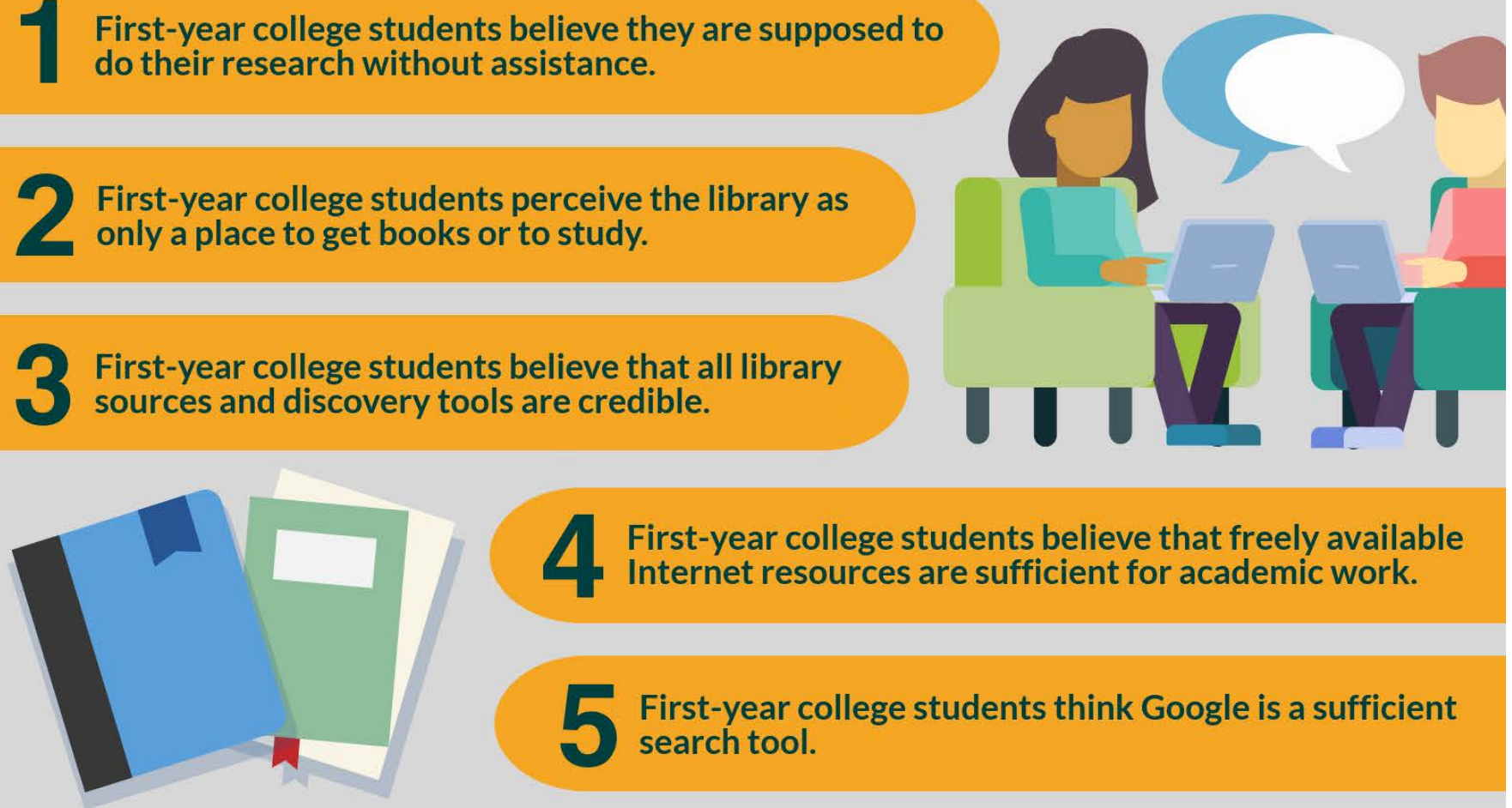

First-year college students believe that freely available Internet resources are sufficient for academic work.

First-year college students believe that accessibility is an indicator of quality.

First-year college students think Google is a sufficient search tool.

First-year college students believe that research is a linear, uni-directional process.

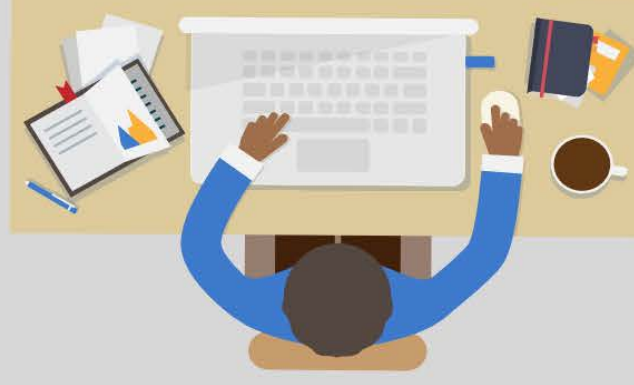
- First-year college students think that every question has a single answer.

Source: Hinchliffe, Lisa Janicke, Allison Rand, and Jillian Collier. Forthcoming. "Predictable Information Literacy Misconceptions of First-Year College Students." Communications in Information Literacy 12 (1).

\section{C.C CREDO}




\section{Assessment as a Marketing Tool}

Assessment strategies not only can be used to improve effectiveness and value of your library's instruction program, they can present opportunities for you to market your library's services and resources. Check out our assessment flow chart to learn how to build an assessment strategy and use the results to market your library.

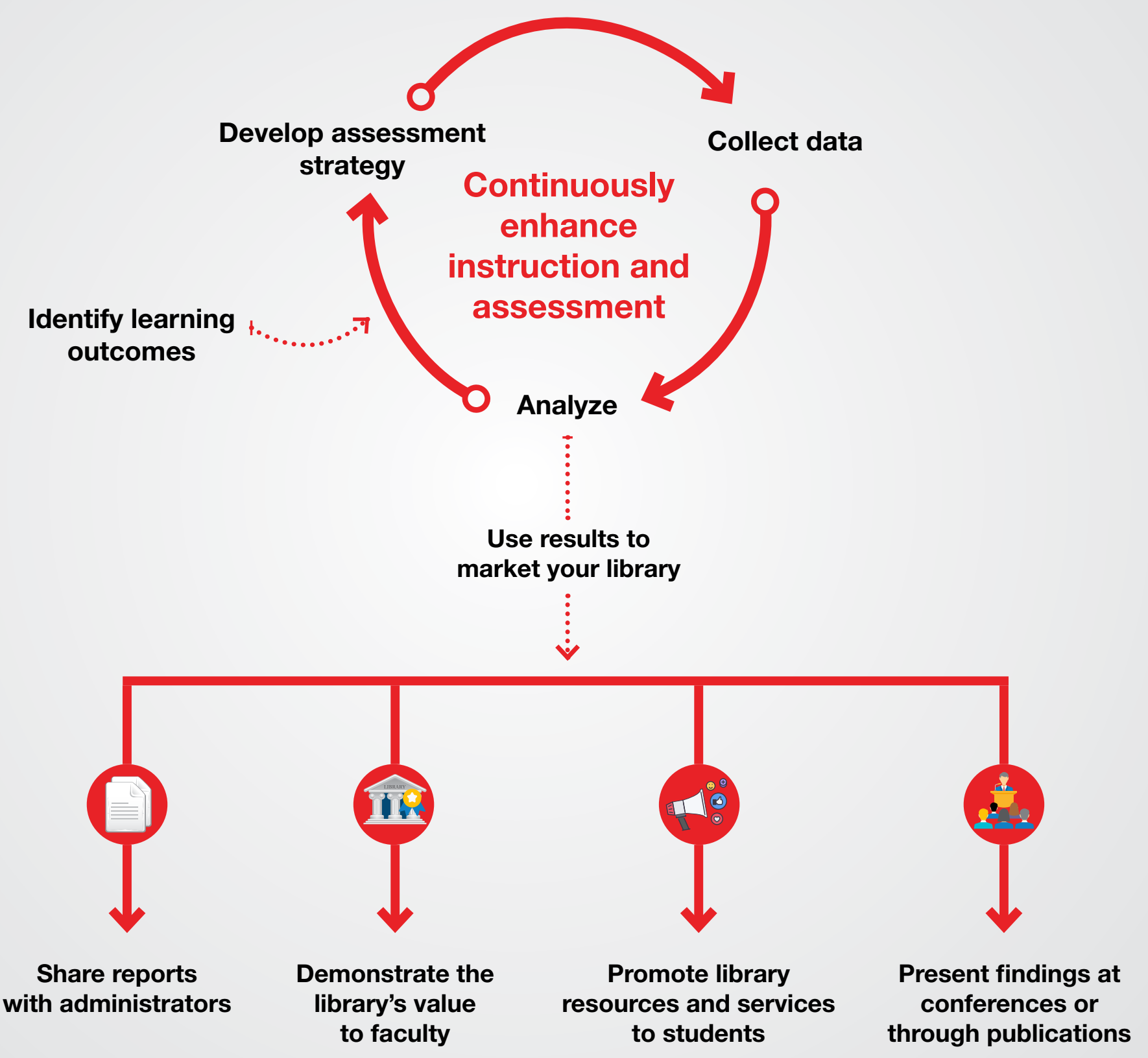




\section{$\{$ The FYE Student Engagement Calendar 10 activities}

to keep students active and interested in the library all year long

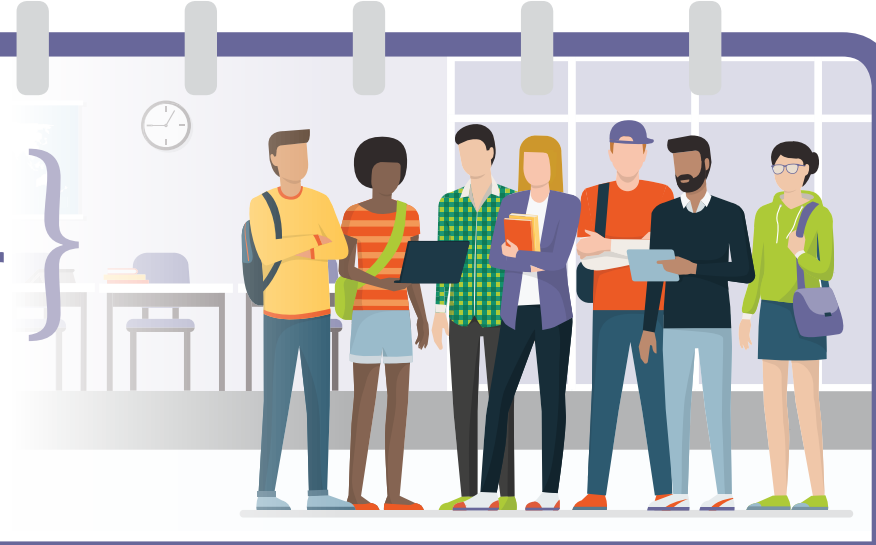

\section{Summer Vacation}

\section{2f Orientation}

\section{Diversity \\ Committee}

Meet to identify any diversity initiatives that might impact the library in the coming year

\section{Physical Space}

Look for opportunities to make the library a more inclusive building, such as lactation rooms or gender-neutral restrooms

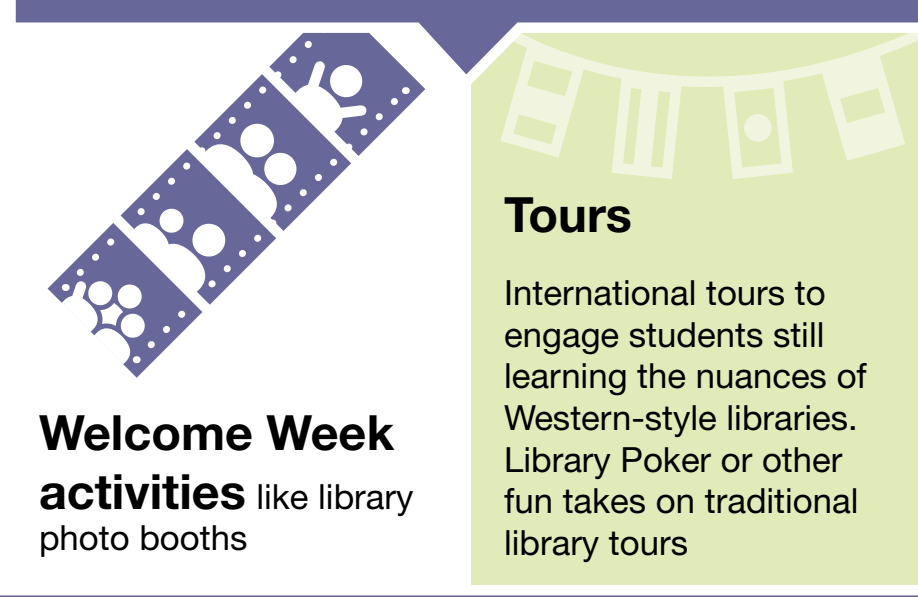

\section{(E) Anytime Engagement}

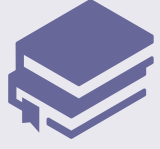

Blind date with a book or movie display

\section{Midterms}

Host a crafternoon

with painting, coloring, or collage-making

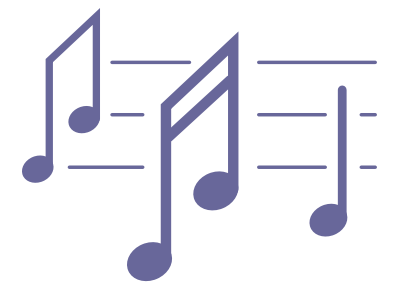

Silent Disco night to loosen students up with music and dancing
Team up with student groups to offer events like a game or poetry night or create exhibits with resources important to them

\section{Therapy dogs in the library}

Let the local media know you're hosting this event for some free press!

\section{Massages or yoga}

Get students' minds and bodies in the right place for exam success 


\section{$\frac{\mathrm{C}}{\mathrm{C}} \mathrm{C}$ CREDO}

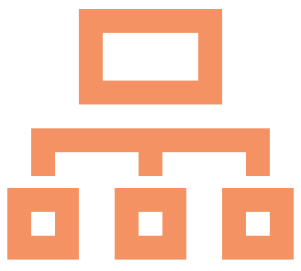

Additional Resources 


\section{Chapter 1: Orientation}

Looking for more helpful tips and tricks? Here are some additional viewing and reading materials to help you plan a great library orientation.

- Fall Library Kick Off: Engaging Orientation Activities by Ray Pun. Further ideas for interactive orientation programming with links to tools and apps to help facilitate activities.

- ACRL Framework for Information Literacy Sandbox An open platform for discussing and sharing materials related to the ACRL Framework for Information Literacy.

- The First Year Library Experience with Ray Pun and Meggan Houlihan. Co-authors of The First-Year Experience Cookbook share best practices and new directions to explore when providing orientation and instruction in the FYE.

- Webinar Recap: The First Year Library Experience Key points from the above webinar to tide you over until you can dig into the full recording.

- Helping Transfer Students Succeed: General Tips

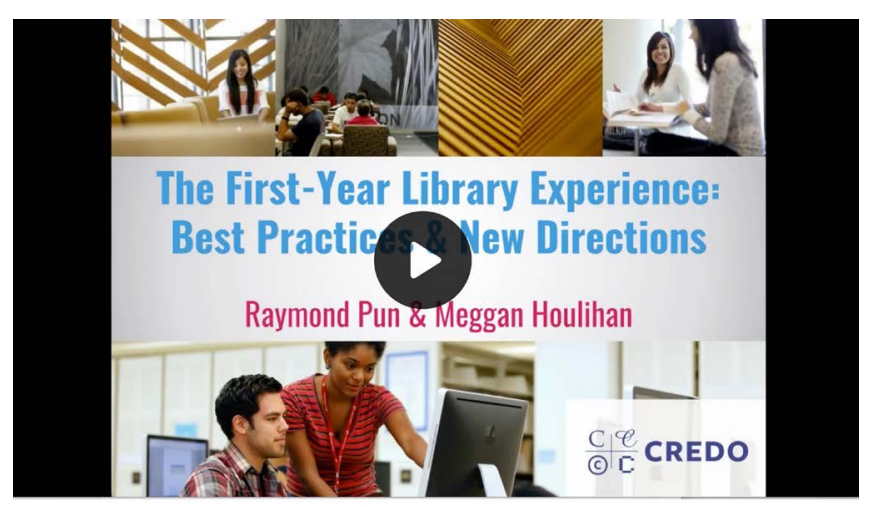
\& Strategies for Academic Librarians by Ray Pun. Further ideas and activities to help better support transfer students through the library.

- Digital Learning Objects: Exploring New Ways to Teach Online Learners by Ray Pun. A recap of discussions from the 2017 ACRL conference around online components of the library FYE.

- Planning Library Orientations by Kylie Bailin, Ben Jahre, and Sarah Morris. Pre-order for June 1st book release.

- Starting Off on the Right Foot: Proven Cases of Successful Orientation Programs A case study overviewing three examples of innovative orientation programming 
Looking for more helpful tips and tricks? Here are some additional viewing and reading materials to help you collaborate with different departments at your institution.

- Collaborative Librarianship: This quarterly journal came to fruition around the scholarship of collaboration and sharing of resources and expertise within and between libraries.

- Collaborating with Student Affairs for Student Success by Ray Pun: Tips for partnering with Student Affairs in order to increase outreach and engagement with first year students.

- Agents of Change: Librarians Innovating in the FYE Space: FYE Innovation Award winners Laura Kohl of Bryant University and Chris Bombaro of Dickinson College discuss how they partnered with individuals and departments to implement effective FYE programming, and how you can replicate their efforts.

- Building Successful Faculty Engagement Programs: Librarians from three different institutions talk about how they've engaged faculty for better partnerships and improved student outcomes.

- A Culture of Collaboration: Library Innovation in the FYE at Bryant University by Laura Kohl: How librarians were able to assume leadership positions and advocate for information literacy in the FYE.

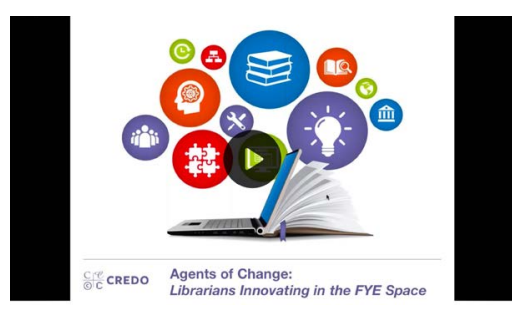

- It Takes a Campus: Successful Collaboration Strategies for Teaching Information Literacy by Chris Bombaro: How Dickinson College's legacy of cross campus collaboration has helped to implement consistent and comprehensive information literacy programs.

- Credo in Action: Faculty Collaboration by Credo: Quotes and stories from academic librarians about the ways in which Credo supports their collaboration efforts with teaching faculty.

- Overcoming Roadblocks To Faculty Collaboration: Librarian Solutions by Credo: Condensed notes from an ACRL conference session where librarians spoke up about challenges with faculty collaboration and offered tips based on their own experiences.

- Teamwork Makes the Dream Work: Bringing the Campus Together Around Information Literacy A case study overviewing the 2018 Inaugural FYE Award winners' FYE programs and their collaboration with different campus groups.

- Collaborating Across Campus An infographic mapping prospective partnerships and activities to collaborate with different groups across campus. 


\section{Chapter 3: Information Literacy}

Below are some helpful and free resources for you to consider to support IL initiatives in classroom instruction.

- Don't Teach the Framework, Framework the One-Shot: by Shawna Thorup: A librarian's guide to embracing the limitations of one-shot instruction sessions to more effectively teach students ACRL Framework concepts.

- First Impressions: LJ's First Year Experience Survey: This Library Journal (LJ) report delves into the survey of 500 librarians conducted by LJ and Credo, revealing the experiences of FYE/instruction/ academic librarians supporting IL in the first year.

- Need visuals to understand or show students how ACRL frames work? These infographics provided by Bucknell University Library convey important and relevant questions surrounding each ACRL frame, and work well for teaching purposes.

- Choice360's "The Authority Files": Important conversations and thoughts in academic librarianship; check out the episode covering The First Year Experience.

- ACRL Environmental Scan Report 2017: This report includes a section on "Information Literacy Issues" and provides a snapshot of trends and the ongoing implications of information literacy, including tackling fake news and teaching digital literacy.

- The ACRL Framework for Information Literacy Sandbox and Project CORA are excellent repositories in which to find advice on a wide range of activities, from creating specialized workshops in the sciences using ACRL frames to teaching basic research skills in first year programs.

- Truth and Assumptions: Views on the Student Research Process: Student and faculty perceptions about student research skills, conducted by Credo in 2016 using survey responses from 1,104 students and 227 faculty members.

- Predictable Misunderstandings in Information Literacy: Initial Research Findings: Lisa Hinchliffe's webinar outlining the methodology behind her research; including a lively Q\&A session with academic librarians.)

- Credo In Action: Teaching Information Literacy: Three academic librarians share how they use Credo Online Research Service and InfoLit Modules to teach information literacy at their institutions.

- A comprehensive Q\&A with Lisa Hinchliffe We asked she answered! An interview with Lisa Hinchliffe on her study Predictable Information Literacy Misconceptions of First-Year College Students.

- Predictable Information Literacy Misconceptions Infographic An Information Literacy infographic covering the nine misconceptions in Lisa Hinchliffe's study by Marissa Ewing, Northwest Arkansas Community College. 


\section{Chapter 4: Assessment}

- Assessing First Year Students: A Conversation on Assessment Techniques with Raymond Pun and Katelyn Angell: Discussion of different techniques to assess first year students in the areas of instruction, user experience, programming, and more.

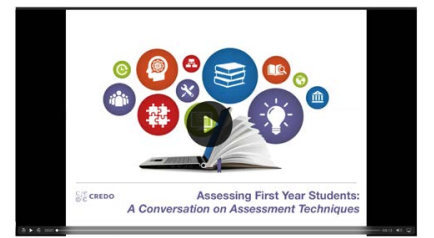

- The Impact of Academic Library Resources on First-Year Students' Learning Outcomes by Krista M. Soria, Kate Peterson, Jan Fransen, and Shane Nackerud, first published in Research Library Issues, no. 290 (2017): 5-20.

- Creative Assessments for the First Year Experience by Katelyn Angell and Raymond Pun: Examples of creative assessment strategies from two FYE librarians.

- More Creative Assessments for the First Year Experience by Katelyn Angell and Raymond Pun: $A$ follow-up to above piece with a focus on collaboration.

- Accreditation and the FYE: Selected Resources for Longitudinal Studies by Raymond Pun: An introduction to participation in the accreditation process for FYE librarians.

- Librarian Parlor: Ideas for librarians conducting and looking to publish their own original research.

- The Library Assessment Cookbook by Aaron W. Dobbs: 80 practical, easy-to-implement recipes for library assessment.

- Creating Sustainable Assessment through Collaboration: A National Program Reveals Effective Practices by Kara J. Malenfant and Karen Brown: synthesis of the results of ACRL's Assessment in Action: Academic Libraries and Student Success program

- Academic Library Impact on Student Learning and Success: Findings from Assessment in Action Team Projects: A comprehensive look at collaborative assessment projects and their results.

- Improving Library, Faculty and Student Performance through Assessment $A$ case study reviewing a college's strategy to measure student progress and improve instruction.

- Assessment as a Marketing Tool An infographic displaying the flow for building an assessment strategy and employing the results as marketing tools. 


\section{Chapter 5: Student Engagement}

\section{Third-party articles}

- Therapy Dogs in Academic Libraries: A Way to Foster Student Engagement and Mitigate Self-Reported Stress during Finals by Mary Renck Jalongo and Theresa McDevitt: An academic article supporting the library's use of therapy dogs as a means to increase student engage and relieve stress

- Higher Education Promotes the Student Experience by Steven Bell: A Library Journal article discussing the value of investing in the student experience and the library's role in creating a pathway for learning and discovery

- How Student Engagement is Important for Libraries by Laura Pitts: A YALSA blog post reviewing a survey conducted discussing students' engagement in their studies and how understanding student engagement can give insights to educators and librarians about challenges affecting learning

\section{Webinars}

- Beyond Information Literacy: 10 Ways to Engage With Your First Year Students by Ray Pun and Katelyn Angell: A webinar recording presenting creative ways to promote library services and resources to first year students

- Gamify the Library: From Creative Instructions to Student Engagement Programs to Support Interactive Learning Experiences by Ray Pun, Andrew Carlos, and Simon Lee: An exploration of gaming and gamification activities to provide librarians with interactive ways to engage with students

\section{Blog Posts}

- Celebrate Money \$mart Week in Your Library by Hiromi Kubo and Ray Pun: Examples of activities to do during different months of the year, focusing on important student topics

- 5 Activities to Support National Poetry Month by Ray Pun: 5 activities to increase your students' awareness in annual observances and cultivate interactive relationships

- HIP In Action: Service- and Community-based Learning in Academic Libraries by Ray Pun: An interview conducted by Ray Pun with several academic librarians discussing their approaches with integrating highimpact practices (HIPs) into their work

- Helping Transfer Students Succeed: General Tips \& Strategies for Academic Librarians by Ray Pun: Ideas and activities to include and motivate transfer students while familiarizing them with library services 


\section{Chapter 5: Student Engagement}

\section{Blog Posts (continued)}

- Celebrate International Education Week in Your Library! by Ray Pun and Hiromi Kubo: Different ways to foster engagement with your international student groups and encourage all students to take advantage of global opportunities at your institution

- Celebrating the FYE: Ideas for Recognizing First Year Students by Ray Pun: Creative activities and contests to acknowledge and reward first year students for completing their first year and encourage further student engagement throughout their academic careers

\section{Credo resources}

- Once Upon a Library: How a Storytime Collaboration Helped Build FYE Engagement $A$ case study overviewing how one library creatively used a community service project to engage students in the classroom and help them develop a deeper connection with the university.

- The FYE Student Engagement Calendar $A$ calendar of 10 activities that will keep students active and interested in the library all year long.
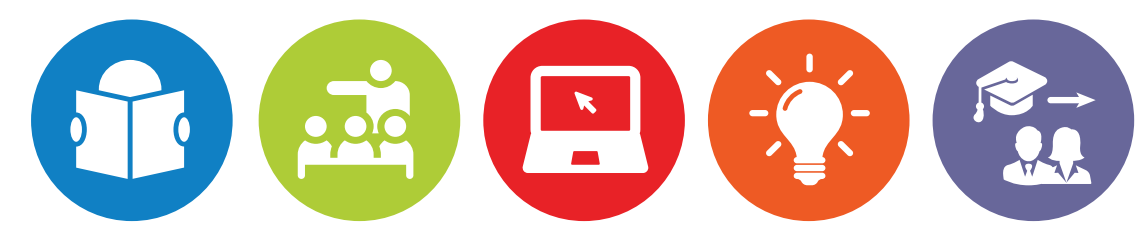

\section{Keep the conversation going using the Twitter hashtag \#LibraryFYE}

